\title{
Lightning activity related to satellite and radar observations of a mesoscale convective system over Texas on 7-8 April 2002
}

\author{
Nikolai Dotzek $^{\mathrm{a}, *}$, Robert M. Rabin ${ }^{\mathrm{b}}$, Lawrence D. Carey ${ }^{\mathrm{c}}$, \\ Donald R. MacGorman ${ }^{\mathrm{b}}$, Tracy L. McCormick ${ }^{\mathrm{d}, 1}$, \\ Nicholas W. Demetriades ${ }^{\mathrm{e}}$, Martin J. Murphy ${ }^{\mathrm{e}}$, Ronald L. Holle ${ }^{\mathrm{e}}$ \\ ${ }^{a}$ DLR-Institut für Physik der Atmosphäre, Oberpfaffenhofen, 82234 Wessling, Germany \\ ${ }^{\mathrm{b}}$ NOAA-National Severe Storms Laboratory, 1313 Halley Circle, Norman, OK 73069, USA \\ ${ }^{\mathrm{c}}$ Department of Atmospheric Sciences, Texas A\&M University, College Station, TX 77843, USA \\ ${ }^{\mathrm{d}}$ Department of Marine, Earth and Atmospheric Sciences, North Carolina State University, \\ Raleigh, NC 27695, USA \\ ${ }^{\mathrm{e}}$ Vaisala-Tucson Operations, 2705 E. Medina Road, Tucson, AZ 85706, USA
}

Received 12 November 2003; accepted 16 November 2004

\begin{abstract}
A multi-sensor study of the leading-line, trailing-stratiform (LLTS) mesoscale convective system (MCS) that developed over Texas in the afternoon of 7 April 2002 is presented. The analysis relies mainly on operationally available data sources such as GOES East satellite imagery, WSR-88D radar data and NLDN cloud-to-ground flash data. In addition, total lightning information in three dimensions from the LDAR II network in the Dallas-Ft. Worth region is used.

GOES East satellite imagery revealed several ring-like cloud top structures with a diameter of about $100 \mathrm{~km}$ during MCS formation. The Throckmorton tornadic supercell, which had formed just ahead of the developing linear MCS, was characterized by a high $\mathrm{CG}+$ percentage below a V-shaped cloud top overshoot north of the tornado swath. There were indications of the presence of a tilted

\footnotetext{
* Corresponding author. Tel.: +49 815328 1845; fax: +49 8153281841.

E-mail address: nikolai.dotzek@dlr.de (N. Dotzek).

URL: http://www.op.dlr.de/ pa4p/ (N. Dotzek).

${ }^{1}$ Current affiliation: National Weather Service, Boston Forecast Office, 445 Myles Standish Blvd., Taunton,
} MA 02780 , USA.


electrical dipole in this storm. Also this supercell had low average CG- first stroke currents and flash multiplicities. Interestingly, especially the average CG+ flash multiplicity in the Throckmorton storm showed oscillations with an estimated period of about $15 \mathrm{~min}$.

Later on, in the mature LLTS MCS, the radar versus lightning activity comparison revealed two dominant discharge regions at the back of the convective leading edge and a gentle descent of the upper intracloud lightning region into the trailing stratiform region, apparently coupled to hydrometeor sedimentation. There was evidence for an inverted dipole in the stratiform region of the LLTS MCS, and CG+ flashes from the stratiform region had high first return stroke peak currents. (C) 2005 Elsevier B.V. All rights reserved.

Keywords: MCS; Severe thunderstorm; Lightning; Satellite; Radar

\section{Introduction}

An interesting leading-line, trailing-stratiform (LLTS) mesoscale convective system (MCS) developed over the Texas panhandle on 7 April 2002 (Massura and Hansing, 2003) and was very well-observed during parts of its 48-h lifetime. In its late stages, the MCS also affected the Texas coastline and moved further offshore, where the system eventually decayed halfway to Florida on 9 April. We first focus on MCS formation including the Throckmorton supercell storm, which formed near the northern tip of the developing linear MCS. Then, the quasi-stationary state of MCS maturity is studied. Our study relies on operationally available total lightning (cloud-to-ground and intracloud), geostationary satellite, Doppler radar and synoptic data.

Previous research on MCS evolution which presents the background for our investigation was reviewed by Houze (1993) and, recently, by Fritsch and Forbes (2001). In particular, we follow the broad MCS definition given by MacGorman and Morgenstern (1998), which includes linear systems (like squall lines) and is not restricted to circular-shaped cumulonimbus clusters below the size of a mesoscale convective complex (MCC, Maddox, 1980):

"A mesoscale convective system is a group of storms which interacts with and modifies the environment and subsequent storm evolution in such a way that it produces a long-lived storm system having dimensions much larger than individual storms.”

When cloud electrification of MCS-type or supercell storms is considered, literature on earlier research is even more voluminous. Comprehensive treatments of lightning in severe storms were given by MacGorman (1993), Houze (1993), MacGorman and Rust (1998) and Williams (2001). Lightning physics by itself is treated by Saunders (1993), MacGorman and Rust (1998), Uman (2001) and Rakov and Uman (2003).

From these, the conceptual model of cloud-to-ground (CG) and intracloud (IC) flashes presented in Fig. 1 has gained widespread acceptance (cf. Williams, 1989; Lang and Rutledge, 2002; Hamlin et al., 2003): There are usually two dominant charge regions present within the storms, a negative charge region between -10 and $-20{ }^{\circ} \mathrm{C}$, and a positive charge region higher up, close to the $-40{ }^{\circ} \mathrm{C}$ temperature level. Aside from this 


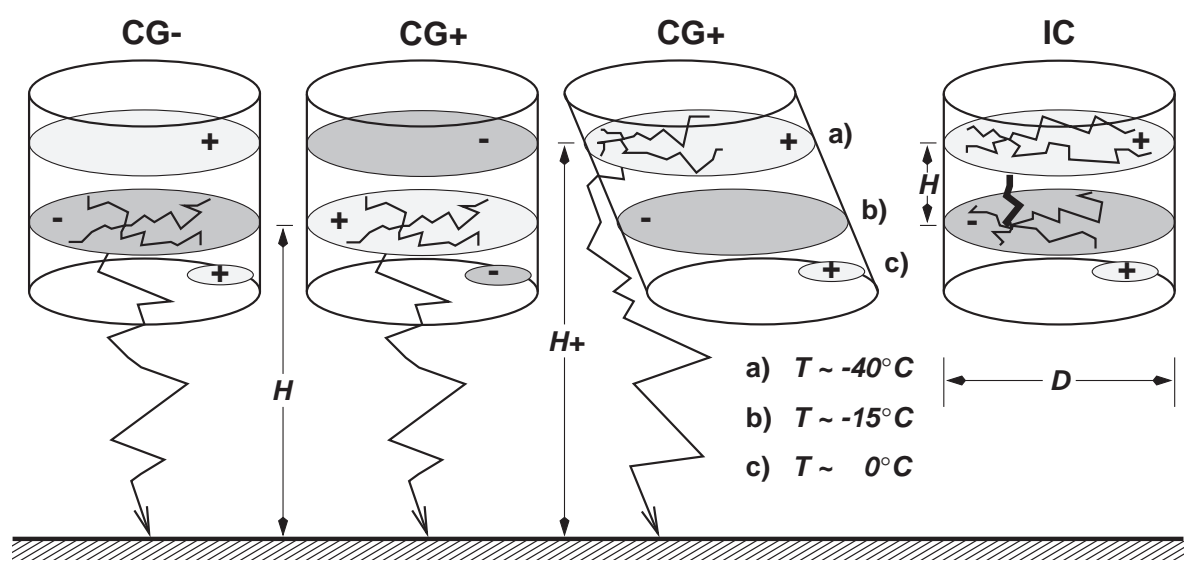

Fig. 1. Conceptual model of lightning types, main charge layers (light gray=positive, medium gray=negative) and their typical in-cloud temperature levels. Note two options for $\mathrm{CG}+$ flashes: (i) inverted dipole, with negative charge above positive charge; (ii) normal polarity, tilted dipole in strongly sheared environments, unshielding the upper positive charge region.

main dipole structure, there may be other, less pronounced charge layers in the thundercloud. For instance, a smaller positive charge region is often found near the freezing level, leading to a tripole setup. Fig. 1 depicts these layers within schematic, cylindrical thunderstorms and shows the possible consequences for CG and IC discharges. The left- and rightmost sketches show negative CG and IC flashes, respectively, for a normal polarity dipole storm with a main positive charge center above the negative main charge center. For the positive CG flash, however, there are two different known processes. The first of these is the inverted dipole in which the charge layering inside the cloud is reversed compared to the normal polarity setup. The second alternative is the tilted dipole, a special case of a normal polarity storm. In a strongly sheared environment that favors development of supercell storms, the upper positive charge center will be shifted downshear from the lower, negative charge region. In this way, the negative charge layer does not shield the positive charge overhead from the ground anymore, so $\mathrm{CG}+$ flashes can occur (cf. Brook et al., 1982; Curran and Rust, 1992), originating from a much greater altitude than positive discharges from an inverted polarity dipole would.

Due to a relative lack of three-dimensional lightning observations in mature MCSs, there are no similar conceptual models of in-cloud lightning structure in the trailing stratiform region of MCSs. Several balloon studies (e.g., Marshall and Rust, 1993; Stolzenburg et al., 1994) of electric fields in the stratiform region of MCSs have inferred multi-layered charge structures there, but few studies have examined in-cloud lightning behavior. Mazur and Rust (1983) found that significantly more lightning occurred in the convective as compared to the stratiform region, where long $(>20 \mathrm{~km})$ flashes tended to occur preferentially. More recently, Lyons et al. (2003) examined the vertical structure of VHF sources associated with 15 sprite-producing CG+ flashes in the stratiform region of an MCS. The average height of VHF sources associated with sprite-producing $\mathrm{CG}^{+}$ discharges was $4.1 \mathrm{~km}$ AGL, close to the melting layer and thus pointing towards meltingcharging mechanisms. 
$\mathrm{CG}+$ flashes from a tilted dipole may provide evidence for presence of a supercell storm. However, successful verification of an inverted dipole with its necessary microphysical peculiarities (Saunders et al., 1991; Saunders, 1993) allows to make judgements on the cloud electrification processes inside the storm. For these reasons, CG+ flashes are a focal point of thunderstorm research. When using total lightning information, it is possible to discriminate between the two possible dipole types. In addition to several studies (e.g., Hamlin et al., 2003) in the USA, Dotzek et al. (2001) showed an example of an inverted dipolar structure in a supercell hailstorm in southern Germany. Much like the analysis by Carey et al. (2005), the lightning data in the present paper encompasses National Lightning Detection Network (NLDN) CG flash data indicating time and location of positive discharges. In the Dallas-Ft. Worth region, a 7-sensor Lightning Detection and Ranging (LDAR II) network provides the necessary IC lightning data to derive a full suite of cloud electrical details of storms passing by. We will use these data to test the validity of the lightning discharge models summarized in Fig. 1.

Geostationary satellites are another useful tool to diagnose and predict severe storm formation and intensification. Studies like those by Purdom (1976), Adler and Fenn (1979a,b), Adler et al. (1985), Adler and Mack (1986), Heymsfield and Blackmer (1988), Schmetz et al. (1997) or the review by Purdom (1993) clearly indicate the different capabilities that satellites have in storm observation compared to ground-based radar. Not only do satellites provide a view of the cumulonimbus cloud top structure, but they also can detect shallow cloud lines atop thunderstorm outflow boundaries, which may serve as zones for new storm formation, but are not yet visible to radar due to the absence of precipitation-sized hydrometeors within them. And in addition, as early as in the late 1970s, Turman and Tettelbach (1980) tried to nowcast storms' tornadic potential by spaceborne lightning detection.

In the present paper, our analysis focuses on the characteristics of lightning evolution during the transition phase from isolated supercells to a mature linear MCS of LLTS type. Similar to the analysis by Zipser and Lutz (1994), we exploit conventional Doppler radar data only. Other studies have also involved polarimetric Doppler radar and lightning detection allowing for hydrometeor classification, either using the S-band (10 cm wavelength, Carey and Rutledge, 1996, 1998; Williams et al., 1999; Hamlin et al., 2003; MacGorman et al., 2003) or the C-band ( $\lambda \simeq 5 \mathrm{~cm}$, Carey and Rutledge, 2000; Dotzek et al., 2001; Fehr et al., this volume) in conjunction with an interferometric total lightning mapper (Defer, 1999; Lang et al., 2000). Moreover, an early total lightning study of a severe storm using L-band radar intracloud lightning detection was presented by MacGorman et al. (1989). Yet, even if no IC lightning data are available, operational national cloud-to-ground lightning detection networks still allow for analysis of electrical activity and storm evolution (e.g., Kane, 1991; Parker et al., 2001; Seity et al., 2003). To detect and determine systematic changes of flash activity and to relate these to satellite and radar observations of thunderstorms can contribute both to our understanding of lightning formation and indicators of impending storm severity.

By combining the analyses by Dotzek et al. (2003), McCormick (2003), Carey et al. (2003b) and the closely related 16 June 2002 LLTS MCS case study by Carey et al. (2005), our work aims to quantify the location of electrical activity with respect to GOES 8 
satellite-derived cloud top structures and WSR-88D radar data. Section 2 of the paper gives a brief overview on the data sources used for our study. In Section 3 on MCS formation, the Throckmorton tornadic supercell and the mature, quasi-stationary LLTS stage of the MCS are analyzed in detail. The obtained results are discussed in Sections 4 and 5 presents our conclusions.

\section{Data description}

Lightning activity of the storms from 7 to 8 April was monitored by two observation systems, NLDN and LDAR II. The two-dimensional NLDN (cf. Cummins et al., 1998; Orville and Huffines, 2001) collects cloud-to-ground flash data including latitudelongitude location and time, polarity, first return stroke peak current ${ }^{2} I_{\max , 1}$ and stroke multiplicity $n$. The NLDN data cover the time span from 7 April, 0000 UTC to 10 April, 0000 UTC. Note that, while the NLDN directly maps each return stroke of a CG flash, the data in our analysis had already undergone some post-processing during which the recorded strokes were grouped into flashes.

However, the NLDN does not provide a complete picture of lightning activity in thunderstorms, as usually the majority of lightning discharges occurs as intracloud flashes (e.g., Boccippio et al., 2001a) of which none or only a very small portion can be detected by the NLDN. Yet in the Dallas-Ft. Worth region, three-dimensional total lightning (CG plus IC) data from an LDAR II network (e.g., Demetriades et al., 2002a,b; Demetriades and Murphy, 2003) operated by Vaisala were available. The network normally consists of 7 sensors with $20-30 \mathrm{~km}$ baselines. Fig. 2 depicts the locations of the LDAR II sensors in the Dallas-Ft. Worth metro area, as well as the KFWS Ft. Worth WSR-88D radar site located approximately $44 \mathrm{~km}$ to the southwest of LDAR II central sensor A.

As also discussed in detail by Carey et al. (2005) in their study of the 16 June 2002 LLTS MCS in the same area, LDAR II can normally map flashes in three dimensions within approximately $150 \mathrm{~km}$ of the network center, degrading in performance with increasing range. However, in the 7-8 April case, the network was somewhat compromised in performance because the two northern and northeastern sensors $\mathrm{B}$ and $\mathrm{C}$ were not operational. As detailed in Appendix A, their loss resulted in decreased lightning flash detection efficiency from more than $90 \%$ (typical value) to $60 \%$ within the ring formed by the network's six peripheral sensors and from approximately $90 \%$ (typical value) to about $20 \%$ at a $120 \mathrm{~km}$ range from the network's central sensor. The location accuracy did not change greatly from 100 to 200 m near the center of the 5-sensor network and less than $4 \mathrm{~km}$ at distances of about $120 \mathrm{~km}$ from the reduced LDAR II network center. Nevertheless, a set of lightning VHF signals ("sources") within $150 \mathrm{~km}$ range around Dallas-Ft. Worth International Airport are available for our study from 7 April,

\footnotetext{
${ }^{2}$ Note that commonly the first return stroke is assumed to have the peak current of a flash. However, this assumption is not fulfilled for all flashes. We therefore chose to use the more appropriate term "first return stroke peak current, $I_{\max , 1} "$ here. See also Lyons et al. (1998).
} 


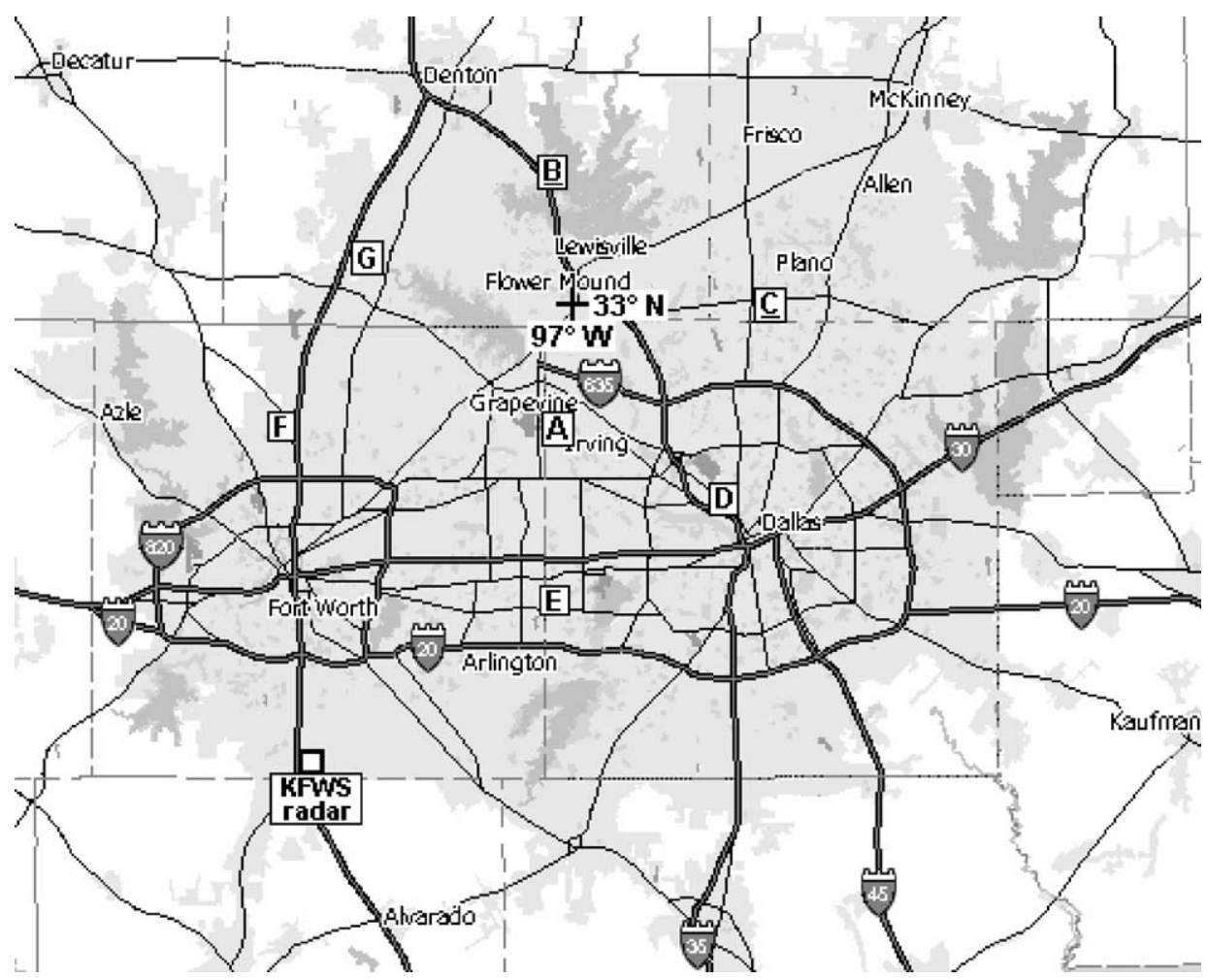

Fig. 2. Dallas-Ft. Worth area map with LDAR II sensors (A, central sensor; B to G clockwise from north) and KFWS Doppler radar locations. Sensors B and C were those not operational on 7-8 April 2002.

0015 UTC to 8 April, 0600 UTC. Note that the Throckmorton storms during MCS formation were beyond the range of the LDAR II network, so total lightning data is only available for the mature LLTS stage of the MCS.

GOES 8 (GOES East) geostationary satellite data have also been recorded and are used to relate lightning activity to cloud top features. The available GOES 8 channel 1 to channel 5 data with $4 \mathrm{~km}$ horizontal resolution cover the period from 7 April, 1200 UTC to 9 April, 1200 UTC. Aside from the visible spectrum (VIS) channel 1, we mainly focus on the analysis of longwave infrared (IR) channel 4, which monitors the spectral band from 10.2 to $11.2 \mu \mathrm{m}$. In this band, the GOES 8 imager only receives emitted IR radiation, making it independent of the amount of incident solar radiation. In addition, channel 4 data allow observations of structures both in the boundary layer and at very high altitude. This makes it attractive for analyses of deep moist convection, especially if brightness temperature $T_{\mathrm{B}}$ grayscale values from medium and high tropospheric levels are further enhanced. We applied the standard MB enhancement table (cf. Reynolds, 1980; Maddox, 1981; McCann, 1983) for thermal IR imagery which redefines grayscale values mainly for brightness temperatures less than $-32{ }^{\circ} \mathrm{C}$ : medium gray -32 to $-41{ }^{\circ} \mathrm{C}$, light gray -41 to $-52{ }^{\circ} \mathrm{C}$, dark gray -52 to $-58{ }^{\circ} \mathrm{C}$, black -58 to $-62{ }^{\circ} \mathrm{C}$ and repeat gray to white shading below $-62{ }^{\circ} \mathrm{C}$. It is most widely used in 
the meteorological community because of the way cold cloud tops $\left(T_{\mathrm{B}}<-62{ }^{\circ} \mathrm{C}\right)$ are highlighted, without losing details of boundary layer structures.

For our analysis, we also rely on S-band (10 cm wavelength) Doppler radar data from two radar facilities. The Throckmorton tornadic supercell storm was well-covered by baselevel reflectivity and Doppler velocity scans from the Dyess Air Force Base radar (KDYX) west of Abilene in northern Texas (Massura and Hansing, 2003). The WSR-88D radar located in Ft. Worth (KFWS, cf. Fig. 2) recorded the mature LLTS stage of the MCS in the Dallas-Ft. Worth area later in the day. Both radars provided useful additional information on the storms' internal structure in order to find interrelationships between radar signatures, satellite-derived cloud tops, NLDN and LDAR II data (for the LLTS MCS only).

Lastly, we use the Weather Services International (WSI) USA national composite (2 km resolution) of WSR-88D reflectivity from base-level scans over Texas and surrounding areas in order to observe the structure and evolution of the 7-8 April MCS throughout its life cycle.

\section{Results}

The thunderstorms which later formed the 7 April MCS developed over west Texas, as a shortwave trough was advancing out of the southwest USA. Atmospheric conditions were favorable for severe thunderstorm formation. Fig. 3a at 1800 UTC shows a warm front over north Texas and a dryline over extreme west Texas. In addition, numerous outflow boundaries over northwest and north-central Texas from overnight convection were present during the late morning and early afternoon (Massura and Hansing, 2003). These features, combined with surface temperatures in the range $23-26{ }^{\circ} \mathrm{C}$, considerable instability indicated by CAPE values from 1500 to $2000 \mathrm{~J} \mathrm{~kg}^{-1}$ with sufficient deep layer shear (cf. the three pre-MCS proximity atmospheric soundings from Midland, Del Rio and Ft. Worth in Fig. 4a-c) enabled rapid thunderstorm development after 1700 UTC in the left exit region of a $300 \mathrm{hPa}$ jet streak (cf. Hane et al., 2002). The first developing storms were isolated supercells (Fig. 5a), but after 1800 UTC, these quickly organized along a line (Fig. $5 \mathrm{~b}-\mathrm{c})$ and later transformed into a large linear MCS extending from south of San Antonio to north of Dallas, moving east-southeasterly (Fig. 5d-i).

GOES 8 channel 4 grayscale MB-enhanced satellite images were computed and investigated for all available satellite scans. Of these, the ones in Fig. 6 were chosen to document the evolution from individual cells on a surface boundary (1715 UTC, labels 1 and 2 in Fig. 6a, cf. Massura and Hansing, 2003) to a line of severe thunderstorms (2025 UTC, Fig. 6b). The $\bigcirc$-symbols indicate ring-like elevated cloud top structures of 50 to 100 $\mathrm{km}$ in diameter within the forming linear MCS. Near the northern tip of the squall line MCS, the Throckmorton storm's rapidly overshooting top takes on a V-shape 8 min before the tornado (cf. McCann, 1983; Adler and Mack, 1986; Heymsfield and Blackmer, 1988) and is marked by a V-symbol in Fig. 6b, which coincides with many NLDN CG strike locations.

Interestingly, there is another strong storm system (a more circular MCS itself) in Fig. $6 \mathrm{~b}$, which had developed in the Dallas-Ft. Worth region more rapidly than the cells along 

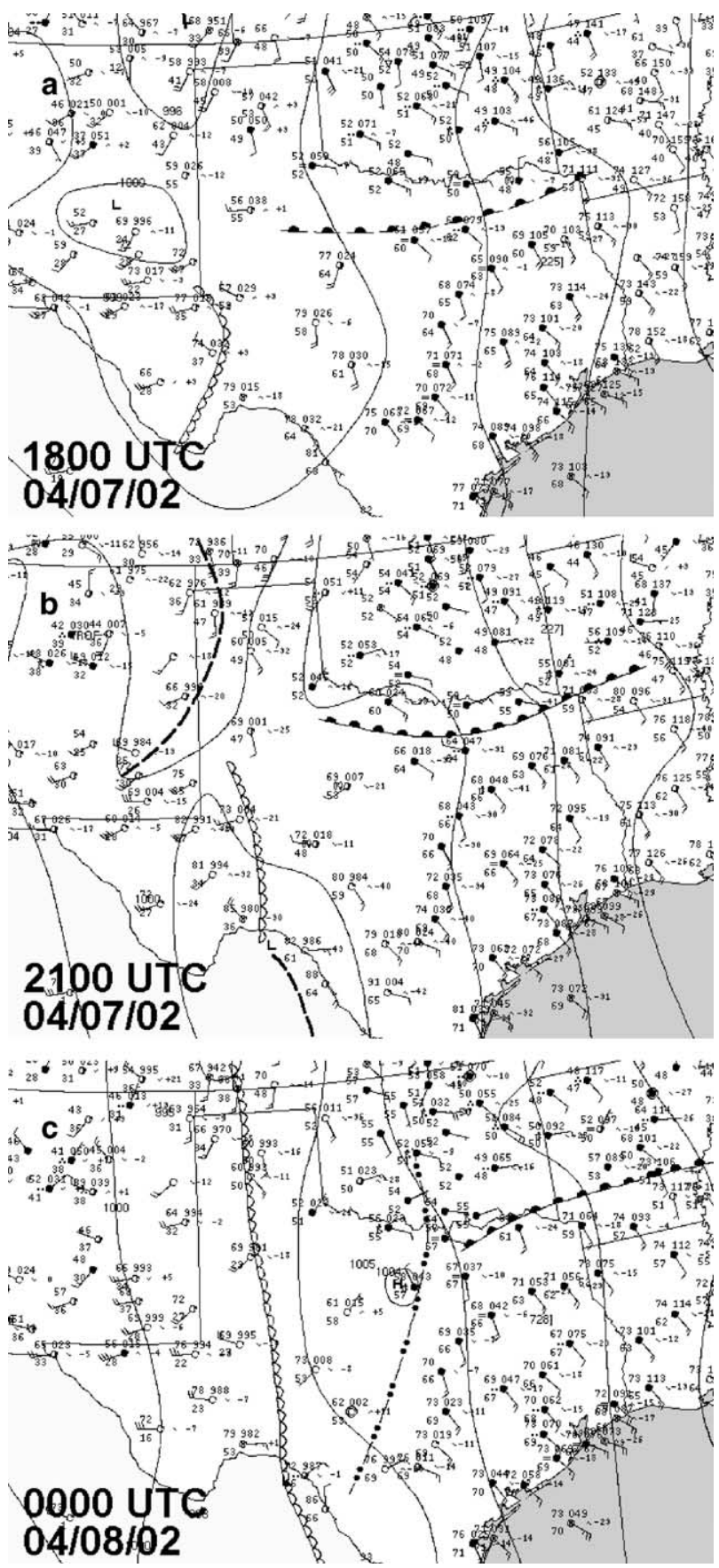

Fig. 3. Surface analysis charts for Texas and surrounding states (Gulf of Mexico shaded in light gray). (a) 7 April, 1800 UTC, (b) 7 April, 2100 UTC, (c) 8 April, 0000 UTC. Note progression of dryline and warm front, as well as the mesohigh behind the instability line in (c) caused by the LLTS MCS. 

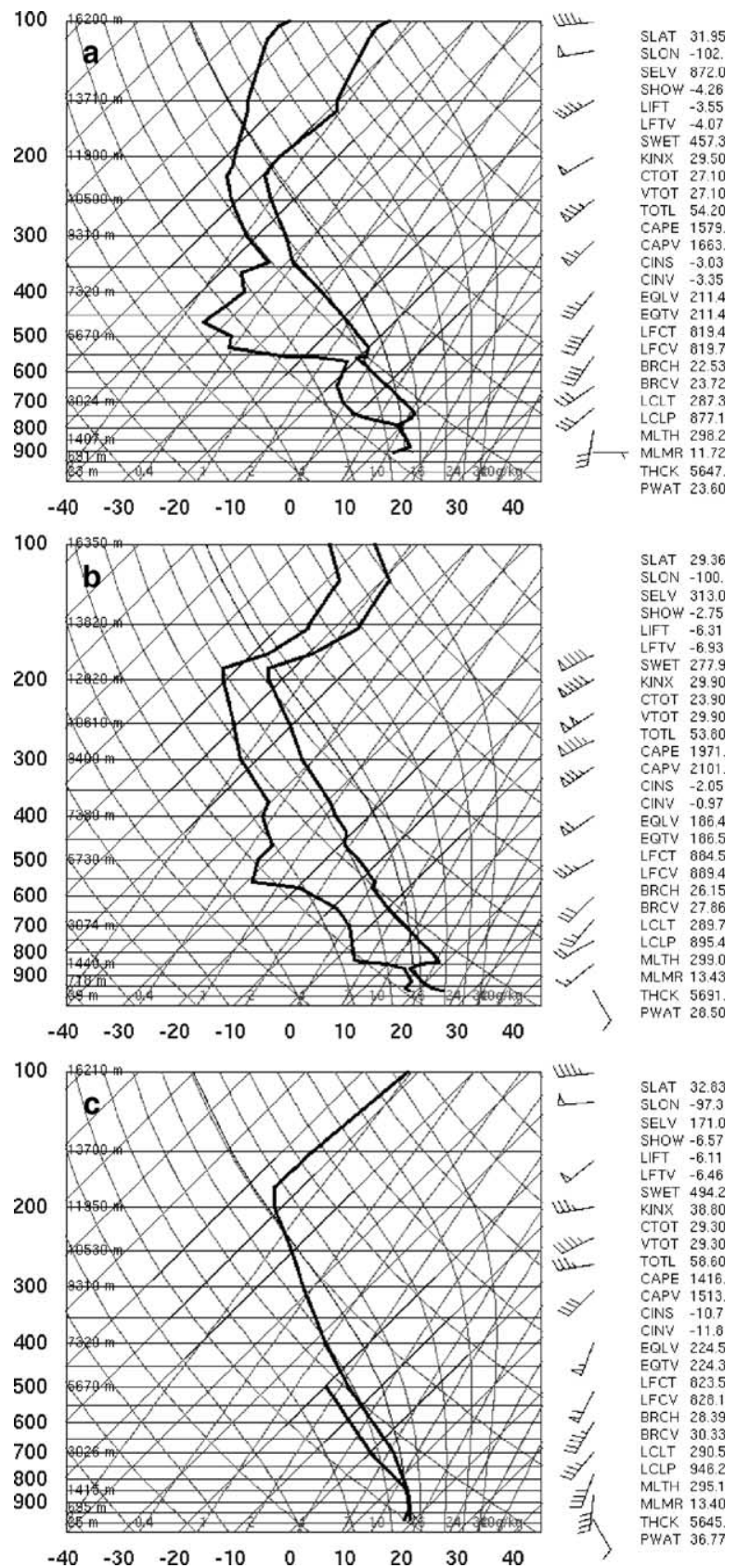

Fig. 4. Atmospheric proximity soundings within the pre-MCS air mass. (a) 7 April, 1200 UTC Midland (MAF), (b) 7 April, 1800 UTC Del Rio (DRT), (c) 8 April, 0000 UTC Ft. Worth (FWD), showing the strongest low-level wind shear and a cold-point tropopause at $-65^{\circ} \mathrm{C}$. Sounding locations are depicted in Fig. 6a. Images courtesy University of Wyoming. 

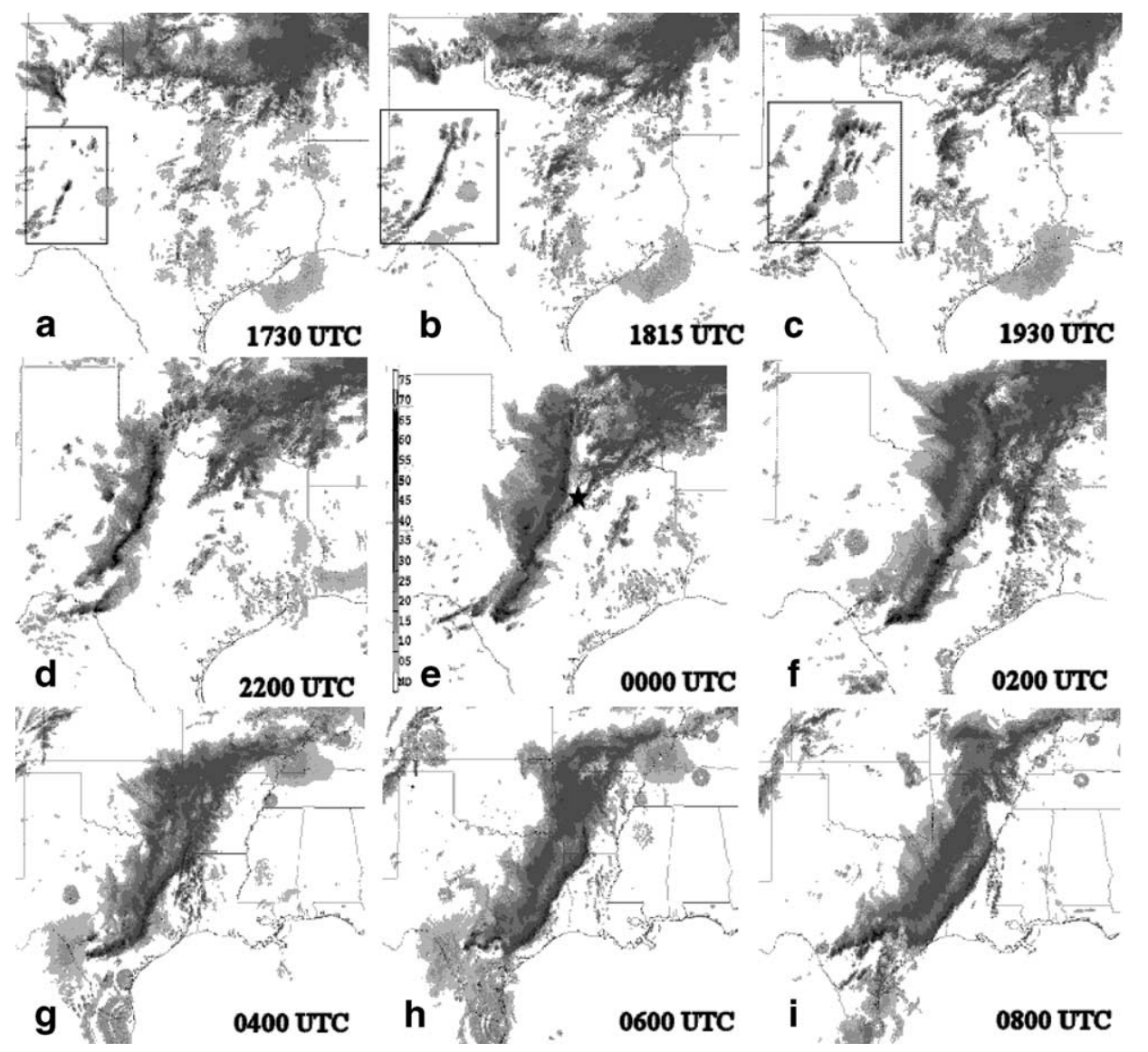

Fig. 5. WSI mosaics of WSR-88D $0.5^{\circ} \mathrm{PPI}$ base-level reflectivity scans over Texas and surrounding areas from 7 April, 1730 UTC to 8 April, 0800 UTC. (a) 1730 UTC, (b) 1815 UTC, (c) 1930 UTC, (d) 2200 UTC, (e) 0000 UTC, (f) 0200 UTC, (g) 0400 UTC, (h) 0600 UTC, (i) 0800 UTC. Note the change in coverage area from panels (f) to (g). In panels (a)-(c), a rectangle is drawn around the developing MCS. In panel (e), a star indicates the approximate location of the center of the LDAR II network. The key to radar reflectivity shading in dBZ for all panels is presented in a bar on the left of (e).

the boundary layer line in west Texas. CG lightning activity in this MCS is almost exclusively confined to the regions of highest cloud tops at that time. The GOES 8 channel 4 imagery reveals that this storm's overshooting cloud top already reached to about the $-70{ }^{\circ} \mathrm{C}$ isotherm. These brightness temperatures are several Kelvin below the cold-point tropopause derived from the 8 April, 0000 UTC Ft. Worth sounding in Fig. 4c. Such a negative offset in $T_{\mathrm{B}}$ has frequently been observed (e.g., Reynolds, 1980; Heymsfield et al., 1983a,b) and is likely caused by transport of air masses within the main updraft cores of the storms (Adler and Fenn, 1979a; Danielsen, 1982). This air arrives at the tropopause level cooler than the ambient air. The satellite-observed brightness temperature is then an average of the temperature in the cold overshooting cloud turrets and the air directly above. And besides, changes in IR emissivity caused by variations in ice particle size 

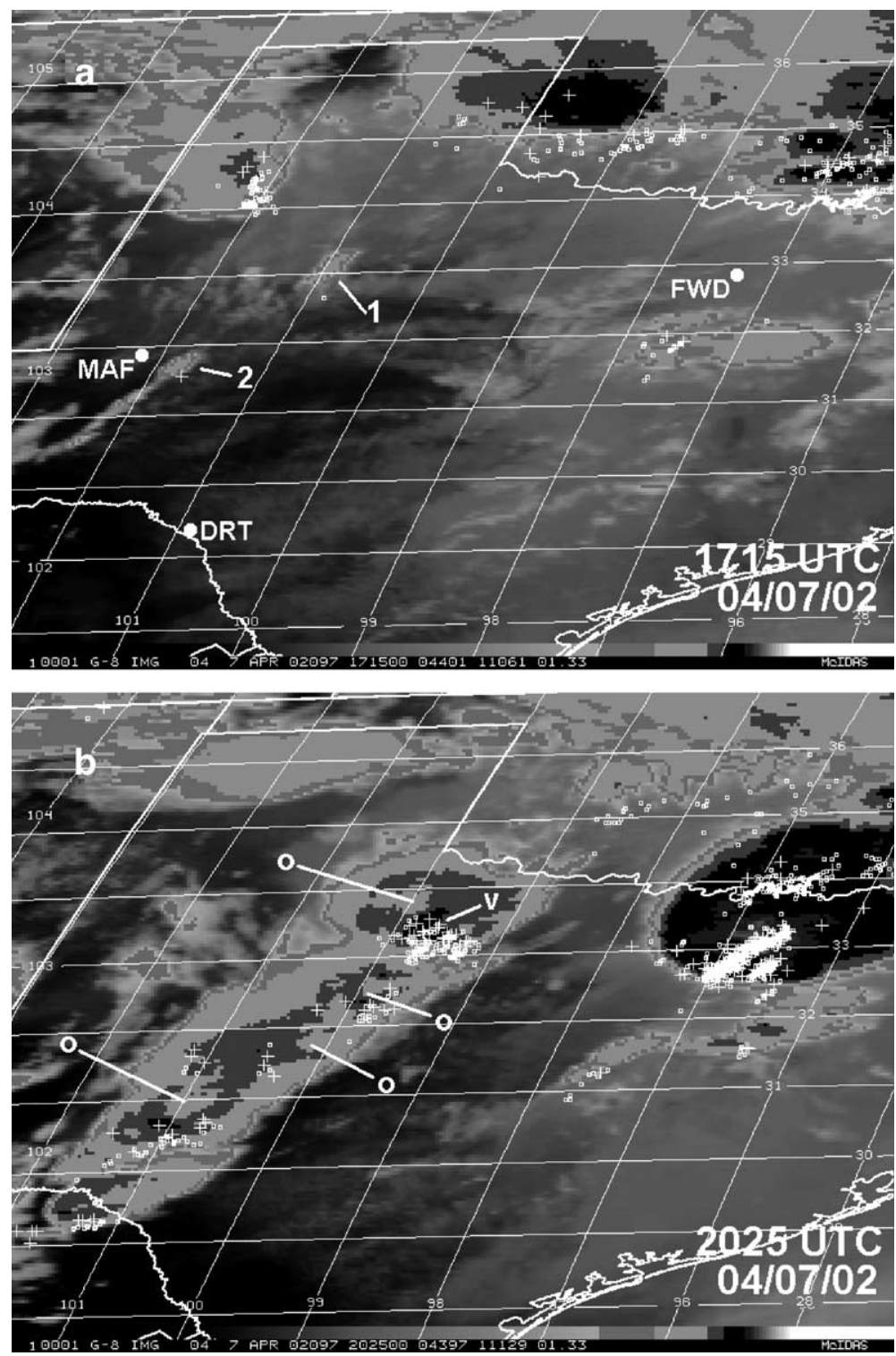

Fig. 6. GOES 8 channel 4 MB-enhanced images from 7 April. (a) 1715 UTC with sounding locations from Fig. 4 and (b) 2025 UTC. NLDN flash overlay ( $+=\mathrm{CG}+, \square=\mathrm{CG}-$ ) $10 \mathrm{~min}$ before to $5 \mathrm{~min}$ after image time. Labels 1 and 2 in (a) indicate convective and CG lightning initiation along the boundary layer line. In (b), the O-symbols point to larger-scale ring-like anvil top structures and the V-symbol gives the V-shaped overshoot of the Throckmorton cell, cf. Fig. 5a-c.

spectra can also lead to altered values of $\mathrm{T}_{B}$ (Adler and Fenn, 1979b). For this reason, estimating cloud top heights from brightness temperature measurements alone is not feasible. Note that this circular MCS later moved north-northeastward into Oklahoma, 
leaving an outflow boundary to the south and east of Dallas-Ft. Worth, which triggered a line of thunderstorms at about 0030 UTC on 8 April.

In general, the NLDN data showed a strong increase in CG lightning activity during squall line evolution towards MCS maturity: For the whole region of Fig. 6a,b, the number of CG flashes per hour was about 250 between 1900 and $2100 \mathrm{UTC}, 380 \mathrm{~h}^{-1}$ between 2100 and 2200 UTC, and then remained between 550 and $685 \mathrm{~h}^{-1}$ for $1-\mathrm{h}$ intervals between 7 April, 2200 UTC and 0100 UTC on 8 April. This provides evidence that after 2200 UTC, MCS size and intensity had apparently reached a quasi-stationary peak level, while after $0100 \mathrm{UTC}$, lightning activity began to drop below $200 \mathrm{~h}^{-1}$ again.

\subsection{Throckmorton supercell}

As shown in Fig. 3a,b, this squall line MCS had developed to the east of the dryline. It was accompanied mainly by damaging straight-line winds and hail, sometimes up to 4.5 $\mathrm{cm}$ in diameter. Several tornadoes were reported as well, most notably the ones near Throckmorton from 2033 to 2050 UTC. $^{3}$ All other tornadoes occurred much further to the south, between 29.1 and $30.6^{\circ} \mathrm{N}$ latitude.

The storm that produced the Throckmorton tornado during the early stages of LLTS MCS formation developed as an isolated thunderstorm around 1920 UTC, ahead of the developing squall line. The storm quickly strengthened and, by 2000 UTC, it began to cross a pre-existing outflow boundary already notable both in GOES 8 VIS imagery and KDYX radar reflectivity data before 1900 UTC. As noted by Rasmussen et al. (2000) and Gilmore and Wicker (2002), this may have played a role for later significant tornado formation and high CG+ flash rates. As early as from 1917 to 1945 UTC, the cell produced hail of at least $2.5 \mathrm{~cm}$ in diameter. At 2033 UTC, the first condensation funnel of a brief F0 tornado formed and reached the surface at $33.18^{\circ} \mathrm{N}$, $99.35^{\circ} \mathrm{W}$. At $2034 \mathrm{UTC}$, the main $\mathrm{F} 2$ tornado formed at $33.18^{\circ} \mathrm{N}, 99.33^{\circ} \mathrm{W}$, about 14 $\mathrm{km}$ west of the city of Thockmorton. The tornado continued to move east-northeast and developed a large funnel. It lasted at least $16 \mathrm{~min}$, from 2034 to 2050 UTC, and its path ended after $11.3 \mathrm{~km}$ at $33.23^{\circ} \mathrm{N}, 99.25^{\circ} \mathrm{W}$. Another large funnel was present to the north of the old one, but it only developed into another brief F0 tornado at the end of the F2 tornado track.

To complement the satellite-viewed boundary analysis by Massura and Hansing (2003) and the reports by ground observers, ${ }^{4}$ Figs. 7-11 focus on GOES 8, KDYX radar and NLDN data for the region and time period of the tornado. Note that total lightning data are not available here, as the Throckmorton storm was out of range (240 km distance) of the LDAR II network, even without loss of two sensors. Fig. 7 documents the cloud top evolution of the Throckmorton storm complex from $23 \mathrm{~min}$ to $8 \mathrm{~min}$ before the tornadoes.

\footnotetext{
${ }^{3}$ Storm reports are available from NOAA's National Climatic Data Center, NCDC and the Storm Prediction Center, SPC.

${ }^{4}$ Jonathan Garner, Brian Thalken and Chuck Doswell provided detailed 7 April 2002 storm chase reports, e.g. www.garnerchase.net/throckmorton.html. Interestingly, the latter account also indicates that the rear-flank downdraft of the Throckmorton storm was warm, probably even slightly warmer than the storm's inflow air, supportive of findings by Markowski (2002).
} 

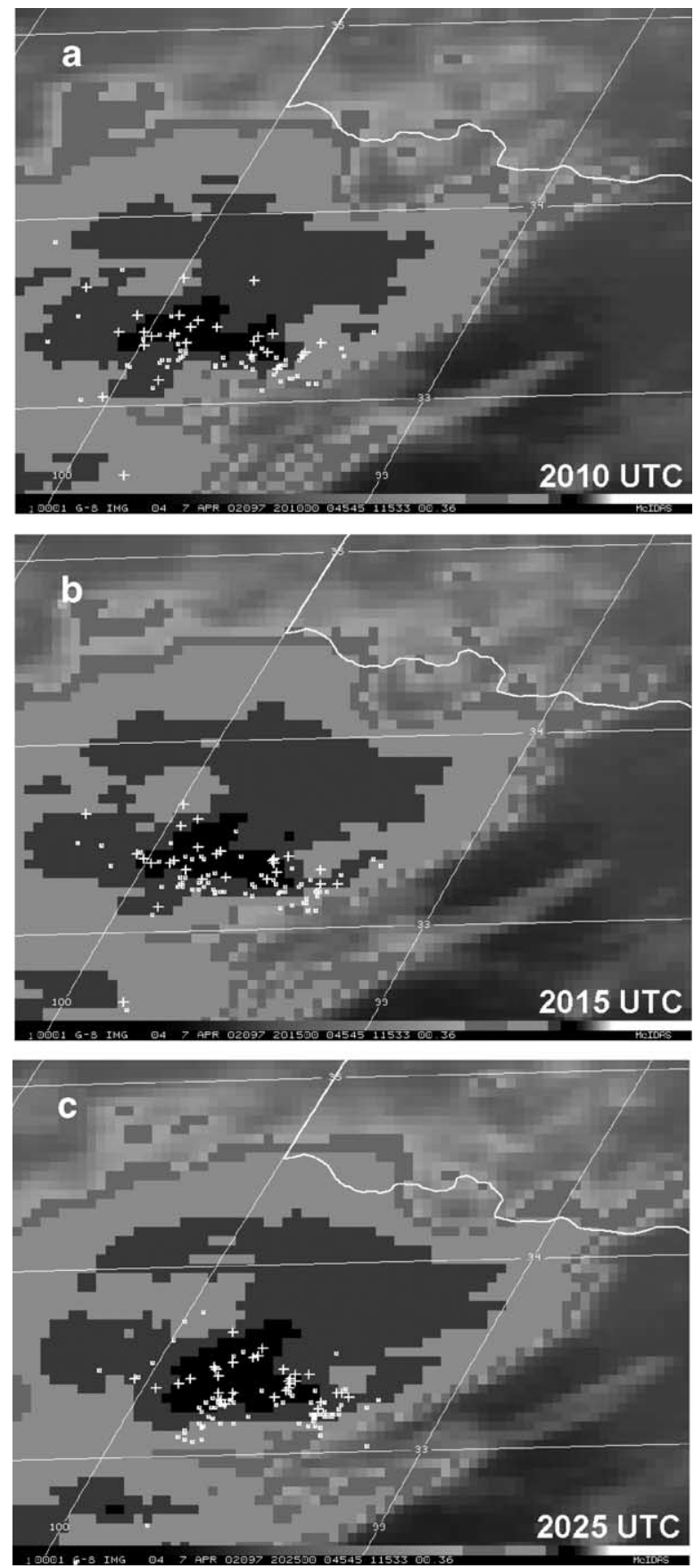

Fig. 7. As Fig. 6, but showing a close-up of the Throckmorton storm evolution before tornado genesis (2033 UTC) for (a) 2010, (b) 2015 and (c) 2025 UTC with NLDN CG flash activity ( $+=\mathrm{CG}+, \square=\mathrm{CG}-$ ) from 5 min before to 5 min after image time. 

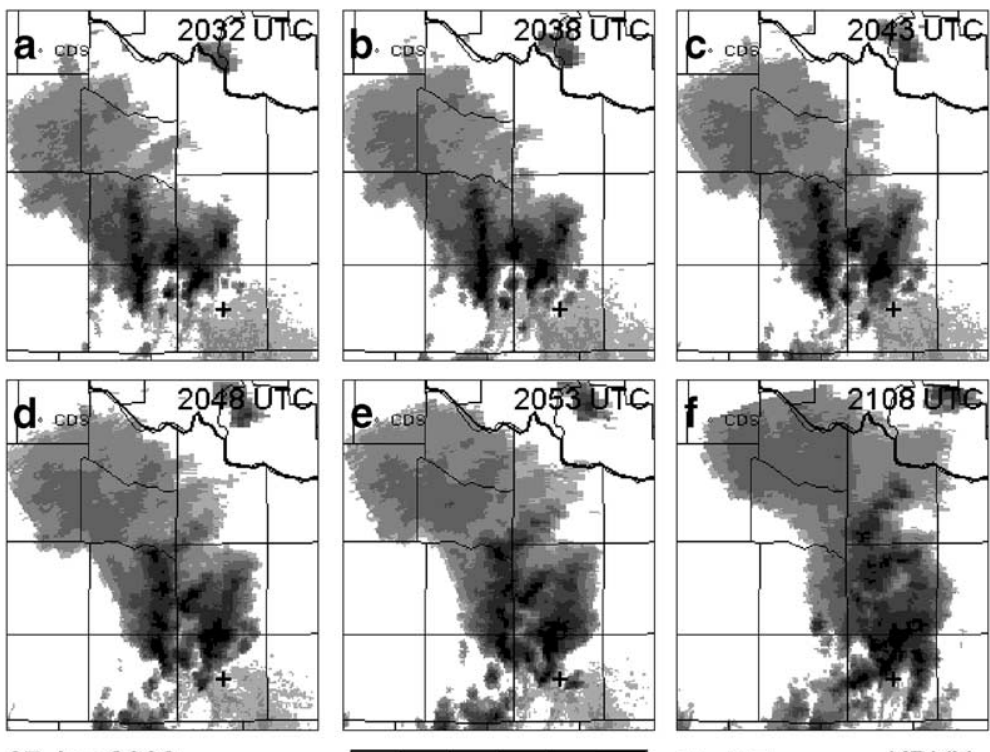

07 Apr 2002

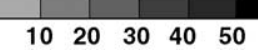

$Z$ in $d B Z$

KDYX

Fig. 8. KDYX $0.5^{\circ}$ PPI base-level reflectivity scans during and after Throckmorton tornadoes. The + marks the location of the city of Throckmorton (cf. Fig. 11), with county limits and part of the Texas-Oklahoma border as an overlay. Throckmorton county size is about $54 \mathrm{~km}$ west-east and $60 \mathrm{~km}$ south-north. The depicted region is similar to Fig. 9 and includes the full stratiform anvil part of the storms (lighter gray shades below $30 \mathrm{dBZ}$ ) for better comparison to the GOES 8 satellite imagery in Fig. 9.

Figs. 8 and 9 cover the tornadoes' lifetimes, from 1 min before tornado genesis to 18 min after its end (Fig. 8) and to 5 min before its end (Fig. 9), respectively.

Fig. 7a,b indicate that most flashes occur in the southeastern sector of the anvil and most $\mathrm{CG}^{+}$are found below the coldest cloud top regions (dark shading). What is also visible here again and in Fig. 7c is the ring-like region of colder and possibly higher cloud tops. This larger-scale feature (100 km diameter) which was seen already several times in Fig. $6 \mathrm{~b}$ is caused by several individual storms beneath the large anvil, at least in the Throckmorton region. The KDYX Dyess Air Force Base radar data at this time (and still visible later at 2032 in Fig. 8a) indicate that a number of cells creates the northern half of the anvil "ring". In the southeastern sector, there is one other electrically active cell westnorthwest of the Throckmorton storm. Other cells lie further west. So in this case, the ringlike cloud tops are a result of the spatial alignment of the initial convective cells.

At 2025 UTC, Fig. 7c still shows the majority of CG+ lightning flashes under the Vshaped cumulonimbus overshoot (cf. Heymsfield and Blackmer, 1988), which has grown in size compared to 2015 UTC in Fig. $7 \mathrm{~b}$. Now, $8 \mathrm{~min}$ before tornado genesis, there are two regions from which higher CG- activity extends southward from the highest cloud tops: (1) the Throckmorton area and (2) further west, near the southernmost tip of the Vshaped overshoot where Fig. 8a indicates another storm.

Focusing now on the tornadic time period of the Throckmorton supercell, Figs. 8 and 9 give base-level radar reflectivity and IR satellite data, respectively, within almost the same 

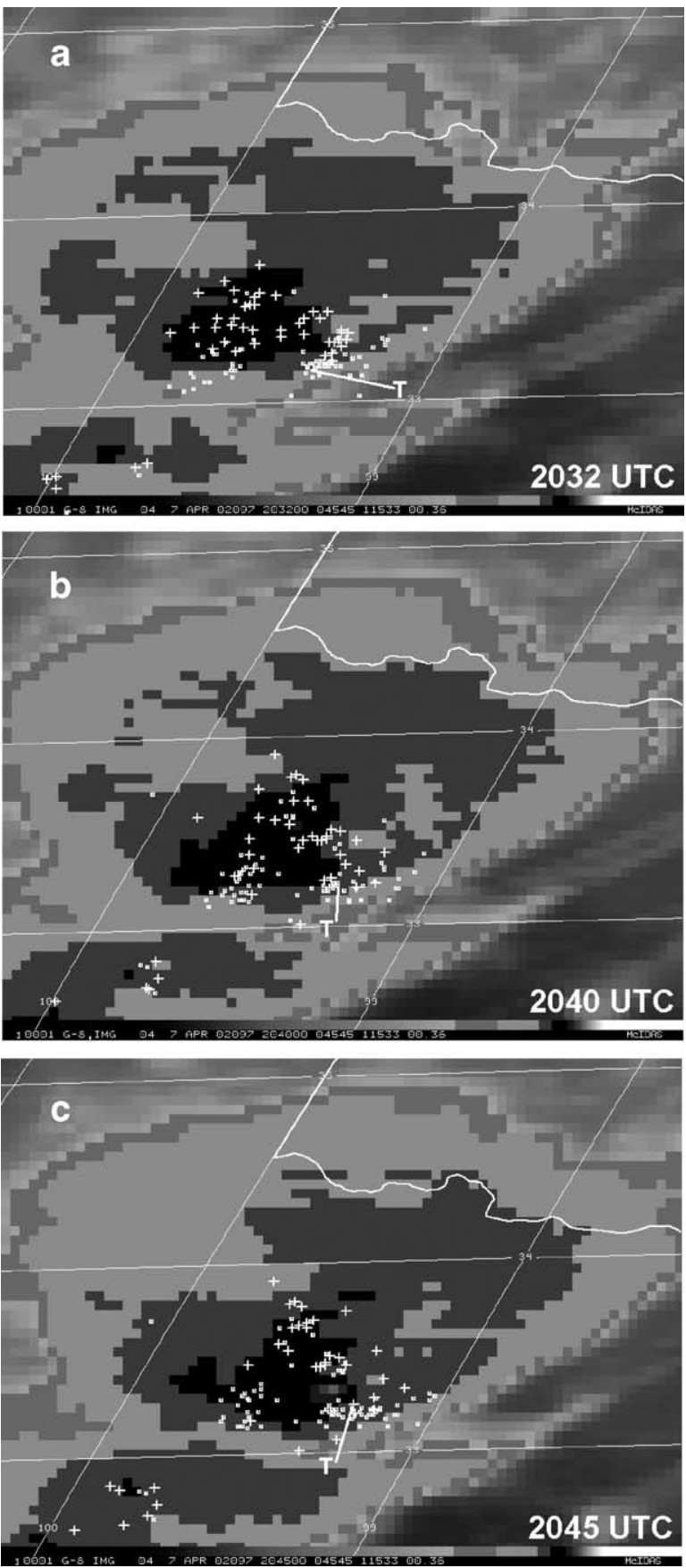

Fig. 9. As Fig. 7, but for (a) 2032, (b) 2040 and (c) 2045 UTC during tornado lifetime (2033 to 2050 UTC). T points to tornado locations based on SPC tornado reports. 

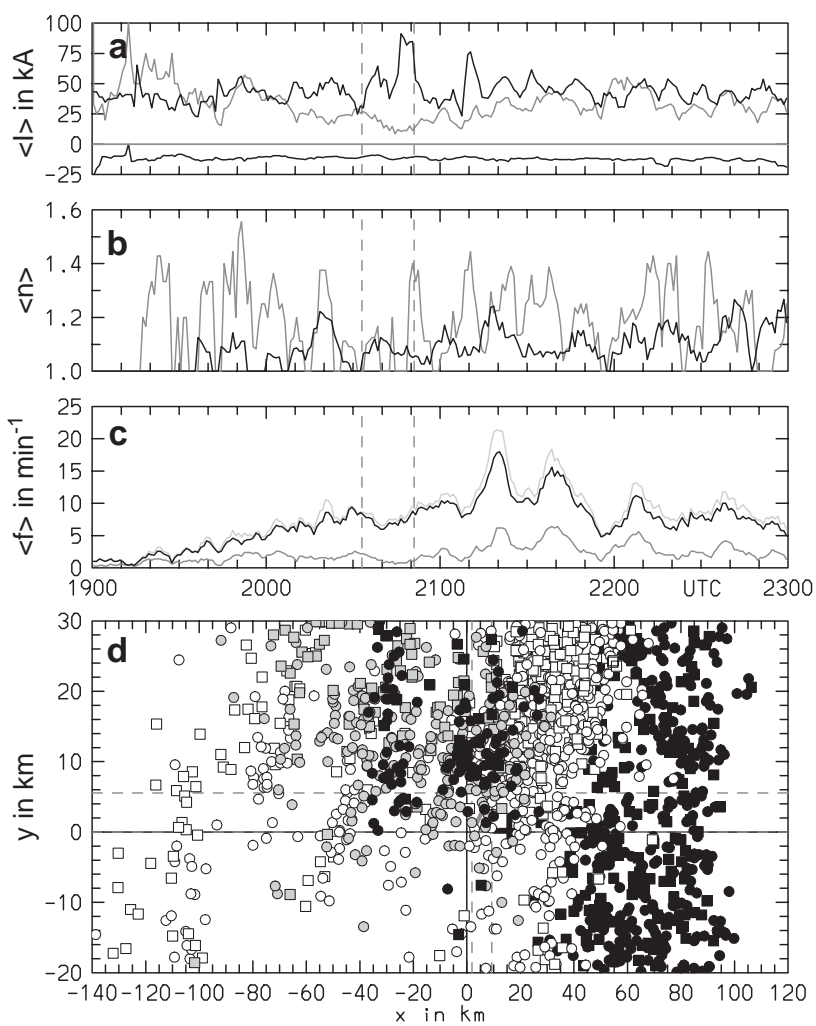

Fig. 10. CG flash analysis in Throckmorton area on 7 April from 1900 to 230 UTC, containing 1711 flashes (534 $\mathrm{CG}^{+}$). Panels (a)-(c) give area-averaged time series (5 min running means). Tornado period is marked by dashed vertical lines. (a) First stroke currents $I_{\max , 1}$ (black) and $\mathrm{CG}+$ percentage (gray); (b) stroke multiplicities $n$ (black $=\mathrm{CG}-$, gray $=\mathrm{CG}+$ ); (c) total $\mathrm{CG}$ flash rate $f$ (black), total stroke rate (upper light gray line), $\mathrm{CG}+$ flash rate (lower gray line). Panel (d) is a planview centered at first F0 tornado report: $\mathrm{O}=\mathrm{CG}-, \square=\mathrm{CG}+\mathrm{F} 2$ tornado track start and end are marked by dashed lines. Grayscale of symbols shows storm propagation: before 2000 white, 2000 to 2100 UTC light gray, 2100 to 2200 UTC white, after 2200 UTC dark gray. Tornadic time (2033 to 2050 UTC) flashes highlighted in black.

domain. In this way, size and location of the stratiform and anvil regions of the thunderstorms as seen by radar and geostationary satellite can be compared.

Fig. $8 \mathrm{a}-\mathrm{c}$ show a clear hook echo in the radar reflectivity core of the cell as it entered Throckmorton county (with the + indicating the city of Throckmorton). Fig. 8c displays the hook echo closest to the conceptual model of a classic supercell storm. Fig. 8d-f document the decaying stage of the tornadoes' lifecycles and the gradual transition to an outflow-dominated storm complex. In Fig. 8d, at 2048 UTC, 2 min before tornado disappearance, the hook echo signature has weakened considerably. Simultaneously, the storms further west have come a lot closer and begin to catch up with the Throckmorton supercell. Here, and already in Fig. 8c, an outflow boundary is visible at the southern tip of these western cells. Fig. 8e shows the beginning cell merger with the Throckmorton storm and also a re-shaping of the hook echo. At 2053 UTC, $3 \mathrm{~min}$ after tornado end, its 

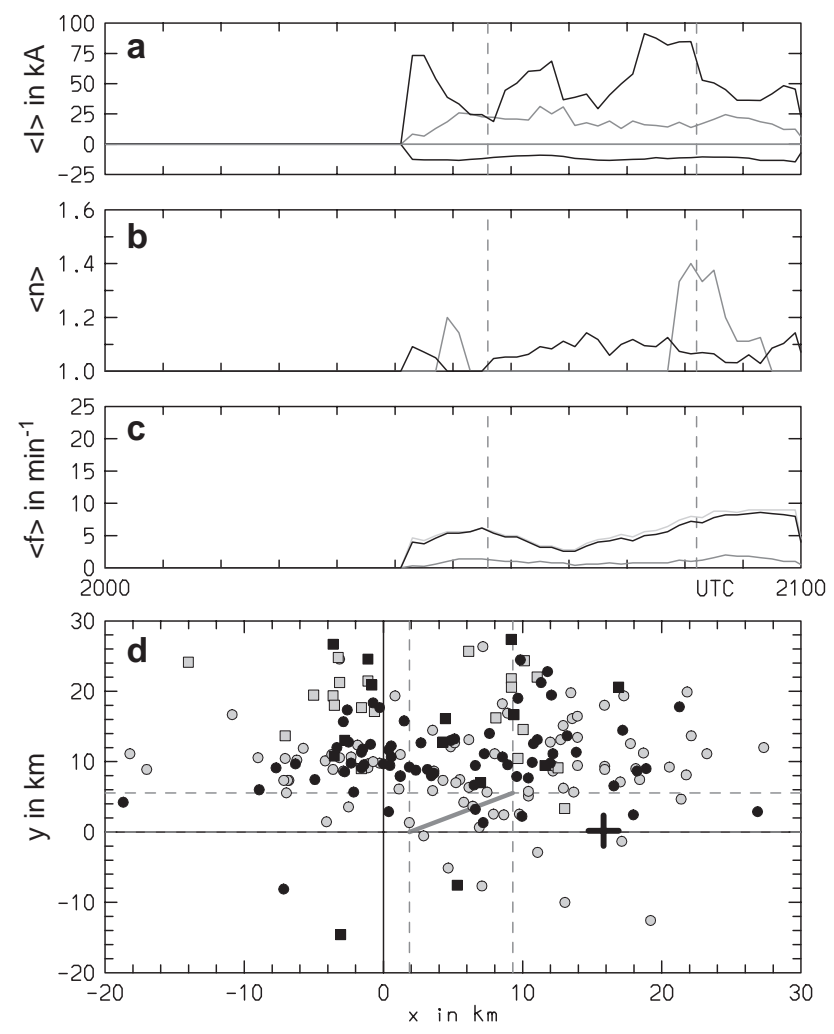

Fig. 11. As Fig. 10, but zooming in on place and time of the Throckmorton tornadoes. In panel (d), 189 flashes ( $35 \mathrm{CG}^{+}$) are plotted, which occurred from 2025 to $2100 \mathrm{UTC}$ within $30 \mathrm{~km}$ of the first F0 and the F2 tornado track (gray, bounded by dashed lines). During tornadic time (2033 to 2050 UTC), 80 flashes were recorded, including $14 \mathrm{CG}+$. City of Throckmorton is marked by the bold + (cf. Fig. 8).

curvature has become reversed, and KDYX radar reflectivity has increased. This is no longer a tornadic hook echo (Markowski, 2002), but an inverted or J-hook structure, indicating that divergent rear-flank downdraft winds have overtaken the supercell's right flank and likely diluted the vortex near the ground.

The rear-flank downdraft of the Throckmorton supercell now pushes forward ahead of the storm. Fig. 8f from 18 min after the last tornado documents the complete cell merger and the formation of two significant arc-shaped outflow boundaries: The one east of Throckmorton caused by the former rear-flank downdraft, and the one still west of the city most likely connected to the cells which had caught up and merged with the supercell from the west. The rapid progression of the cells west of the Throckmorton storm led to a shrinking of the weak echo region between the cells - and likely corresponds to the disappearance of the ring-like cloud top structure of the whole system visible in the GOES 8 images of Fig. 9.

Comparing the KDYX radar observations to satellite imagery and CG flashes, Fig. 9a at 2032 UTC (1 min before tornado formation) shows significant $\mathrm{CG}+$ activity north of the tornado and still the two southern tips of concentrated CG-flashes identified in Fig. 7c (cf. 
Keighton et al., 1991). Simultaneously, the ring-like cloud top structure starts to vanish from the northwest. The T-symbol indicates the location of the first Throckmorton tornado as it formed at 2033 UTC. Apparently, the tornado vortex and the coldest cloud tops show considerable spatial separation.

Moreover, the high areal density of $\mathrm{CG}-$ at the southern flank of the Throckmorton cell seems to wind or spiral around the location of the tornado. That suggests a preference for CG- discharges from the hook echo region of the supercellular storm. Recall that the 2032 UTC, KDYX base-level radar reflectivity in Fig. 8a indeed indicated a hook echo structure. But due to the large distance of $240 \mathrm{~km}$ from Throckmorton to the Dallas-Ft. Worth LDAR II network, no VHF total lightning data is available to perform an analysis like, for instance, Krehbiel et al. (2000) and Hamlin et al. (2003) did in order to investigate if the main updraft region in the center of the hook is also void of IC lightning. As will become evident from the CG flash analysis below, at least a portion of the tornado swath below the hook echo was free of nearby CG strikes, in accordance with findings by MacGorman (1993).

During the later stages of the tornado, Fig. 9b,c show that lightning activity near the highest cloud tops more and more spreads into three different centers: one region to the north, the former tip of the V-shaped region and the tornadic storm. In Fig. 9c, we can see that near the tornado, mainly $\mathrm{CG}-$ flashes occur, whereas $\mathrm{CG}+$ discharges are still more confined to the left, northern flank of the storm. Also note the further decrease in cloud top brightness temperature for the Throckmorton supercell, which might be indicative of a strengthening updraft and a new overshooting cumulonimbus turret.

By this time, 2045 UTC, also the hook echo in Fig. 8c was most well-defined. From these observations, one might argue that the tornado was now probably in its most intense phase, caused by vortex stretching due to the vigorous updraft within the mesocyclone. Yet as the tornado only passed over open country with few objects to be damaged, no clear evidence from a tornado damage survey is available to verify this. The ring-like structure at the cloud top has also broken up completely, confirming the radar observation that the cells further west have caught up with the leading ones in the process of squall line formation (cf. MacGorman and Nielsen, 1991). The surface analysis at 2100 UTC in Fig. $3 \mathrm{~b}$ also shows how both the dryline and the warm front have advanced during this phase of MCS formation while in eastern Texas, strong inflow towards the developing squall line still prevails.

Fig. 10 focuses on solely NLDN CG flash activity in the greater Throckmorton area between 1900 and 2300 UTC, where 1711 flashes occurred of which 534 (i.e., 31\%) were of positive polarity. Fig. 10a-c give area-averaged time series ( 5 min running means of NLDN data with 1 min resolution). Tornado period is marked by the dashed vertical lines. The following can be noted from the figure: (1) CG- flash multiplicity $n$ is generally low, showing values of only $n=1.1$ to 1.3 , so average flash and stroke rates do not differ much. (2) Remarkable are the higher $n$-values for the $\mathrm{CG}^{+}$flashes. In general, the contrary is more likely to be true. (3) The percentage of CG+ flashes was quite high, usually varying between $25 \%$ and $50 \%$. The lowest percentage occurred near the end of the tornado, simultaneously with a local maximum of average $\mathrm{CG}+$ first stroke current. Another local peak in $I_{\max , 1}$ of $\mathrm{CG}+$ was detected during the first half of the tornado lifetime. Total CG 
flash rate dropped to a minimum after half the tornado lifetime. (4) Peak CG+ currents were at a local minimum at tornado genesis. Peak $\mathrm{CG}-$ currents were rather low and ranged between -10 and $-20 \mathrm{kA}$ with little temporal variation.

In Fig. 10a,c, there appears to be an interesting trend of generally decreasing $\mathrm{CG}^{+}$ percentage mainly tied to increasing $\mathrm{CG}_{-}$(and not declining $\mathrm{CG}^{+}$) flash rate, which begins about 30 to 40 min prior to tornado genesis and continues through the end of the three reported tornadoes. The $\mathrm{CG}^{+}$percentage continues to go up for an hour after the end of the last tornado. The total CG flash rate also seems to increase after the tornadoes and there is a relative minimum in the total CG flash rate during the F2 tornado.

Interestingly, mainly for the $\mathrm{CG}+$ but also for the $\mathrm{CG}-$ flash multiplicities in Fig. 10b, there is a quite pronounced periodicity in the $n$-values. A rough estimate of the repetition time is 15 min over the whole time period. From this time series alone, it remains unclear if this reflects either a cloud dynamical or microphysical cycle relevant for cloud electrification, a statistical sampling effect or if it is purely coincidental. Some arguments supporting cloud microphysical reasons and a special NLDN stroke data reanalysis for this region will be presented in the discussion.

From the planview in Fig. 10d, it is again seen that the majority of $\mathrm{CG}+$ discharges in the east-northeastward propagating storms before 2200 UTC occurs to the north of the tornado. The Ft. Worth sounding from 0000 UTC on 8 April in Fig. 4c indicates southwesterly winds at mid to upper-tropospheric levels, so the northward shift of $\mathrm{CG}^{+}$ activity may be due to discharges from the sheared anvil region, giving evidence for a tilted dipole within the cumulonimbus core, as illustrated in Fig. 1.

Fig. 11 is a close-up in space and time on a smaller region (approximately the size of Throckmorton county shown in Fig. 8) around the three observed tornadoes between 2000 and 2100 UTC. Panels (a)-(d) have the same meaning as in Fig. 10. The origin in Fig. 11d is again given by the first F0 tornado location. The damage swath of the F2 tornado is plotted as a bold gray line, with its start and end points bounded by the dashed gray lines. Recall that at the end of the F2 tornado path, another brief F0 tornado occurred. The city of Throckmorton is marked by the large +-symbol (cf. Fig 8). Within this frame of reference, 189 CG discharges occurred, among which 35 were positive flashes (i.e.19\%). During the 17-min tornadic period, $80 \mathrm{CG}$ flashes occurred: 14 were $\mathrm{CG}+(18 \%)$ and 66 were of negative polarity. All these lightning strikes occurred within $30 \mathrm{~km}$ of the three tornado tracks. This criterion was chosen such that only flashes from the Throckmorton supercell were recorded.

Fig. 11d reveals the $\mathrm{N}-\mathrm{S}$ spatial separation of $\mathrm{CG}^{+}$and $\mathrm{CG}-$ flashes: Only three positive ground strikes occurred southward of the tornado track's end point, all other $\mathrm{CG}^{+}$ were recorded 5 to $28 \mathrm{~km}$ north of the tornadoes. The radar images in Fig. 8 had shown that this northward region contains the main precipitation core of the hook echo, so these positive $\mathrm{CG}$ - strikes apparently did not develop from a true stratiform region (with $Z$ less than $30 \mathrm{dBZ}$ ) of the storm. Instead, the observed downshear displacement of the $\mathrm{CG}^{+}$ flashes from the storm's main updraft region seems to confirm the presence of a tilted dipole in the supercell according to the schematic in Fig. 1. As Fig. 11a shows, the CG+ flashes nevertheless had rather large first return stroke peak currents with a maximum of about $90 \mathrm{kA} 5 \mathrm{~min}$ before the end of the F2 tornado. At the same time (2045 UTC), Fig. 9c had revealed a new, very cold cumulonimbus turret, and the hook echo in Fig. 8 was most 
clearly defined. So the peak in $\mathrm{CG}+$ return stroke current may be coupled to this strengthening of the storm's updraft.

Fig. $11 \mathrm{~b}$ shows a very low multiplicity of the $\mathrm{CG}-$ strikes and an interesting behavior of the $\mathrm{CG}+$ flashes: $\mathrm{CG}+$ multiplicity only differs from $n=1$ shortly before tornado genesis and few minutes before the end of the tornadic phase. Average multiplicity of the $\mathrm{CG}+$ flashes at the end of the F2 tornado is rather high with $n$-values of about 1.4, similar to the peaks already seen in Fig. 10. Another feature of Fig. 10c is reproduced in Fig. 11c: The total CG flash rate shows a minimum at 2040 UTC, near half the tornadoes' lifetime.

\subsection{Mature stage of the MCS}

During the remaining hours of 7 April, the squall line merged with the remnants of a precipitating system in southeast Oklahoma and the earlier Dallas-Ft. Worth circular MCS and evolved into an east-southeastward-moving linear system with leading-line, trailingstratiform characteristics (Fig. 5e-i). The now mature LLTS MCS also was an effective rain producer. In the late afternoon and evening hours (roughly 2330 to 0100 UTC), heavy precipitation led to flash flooding in the Dallas-Ft. Worth area. Rainfall accumulation was $81 \mathrm{~mm}$ at Dallas-Ft. Worth international airport, surpassing the record mark of $78.5 \mathrm{~mm}$ in $24 \mathrm{~h}$ from the year 1900, and parts of north Texas received up to $127 \mathrm{~mm}$ precipitation.

Figs. $3 \mathrm{c}$ and $4 \mathrm{c}$ show the surface analysis and the Ft. Worth sounding at 0000 UTC on 8 April. As the instability line in Fig. 3c shows, the Dallas-Ft. Worth metroplex was still slightly ahead of the advancing LLTS MCS in the air mass with south-easterly inflow towards the storms. The dryline remained far behind the MCS over the Texas panhandle. Note the mesoscale high pressure area just behind the instability line, about halfway between Throckmorton and Dallas-Ft. Worth. Mesohighs as this one are caused by mesoscale descent at the rear flank of squall lines and may play a role in creating a convectively "passive" zone between the leading line and the trailing stratiform region of the MCS.

At this stage, the storms in this area were accompanied by frequent and horizontally extensive IC lightning activity, noted by ground-based observers and confirmed by the LDAR II data. Also, the CG flashes now started to concentrate in a remarkably sharp convective leading edge, visible in the NLDN flash overlay of Fig. 12 at 0115 (a) and 0202 UTC (b).

Fig. 12a documents some cloud-electrical variations along the young LLTS MCS. In the southern part of the line, there appears to be the highest density of CG strikes and the strongest focusing of lightning activity along a narrow line almost centered within the broad high cloud shield. Furthermore, positive flashes are either close behind or far ahead of the MCS. Thus, in southern Texas, the MCS shows more characteristics of a symmetric MCS. Northward of $32^{\circ} \mathrm{N}$, these characteristics change towards the LLTS MCS, with few $\mathrm{CG}-$ flashes ahead of the line and many $\mathrm{CG}^{+}$discharges far behind the line. The cold cloud tops in this area (Fig. 12a,b) and the horizontal radar reflectivity structure (Fig. 5e,f) also reflect the LLTS geometry from well-known conceptual models (e.g., Houze, 1993). Nevertheless, there is still considerable heterogeneity in this northern section of the squall line. Near the Texas-Oklahoma border, the lightning locations indicate several parallel smaller-scale convective line segments in the main leading convective zone. This 

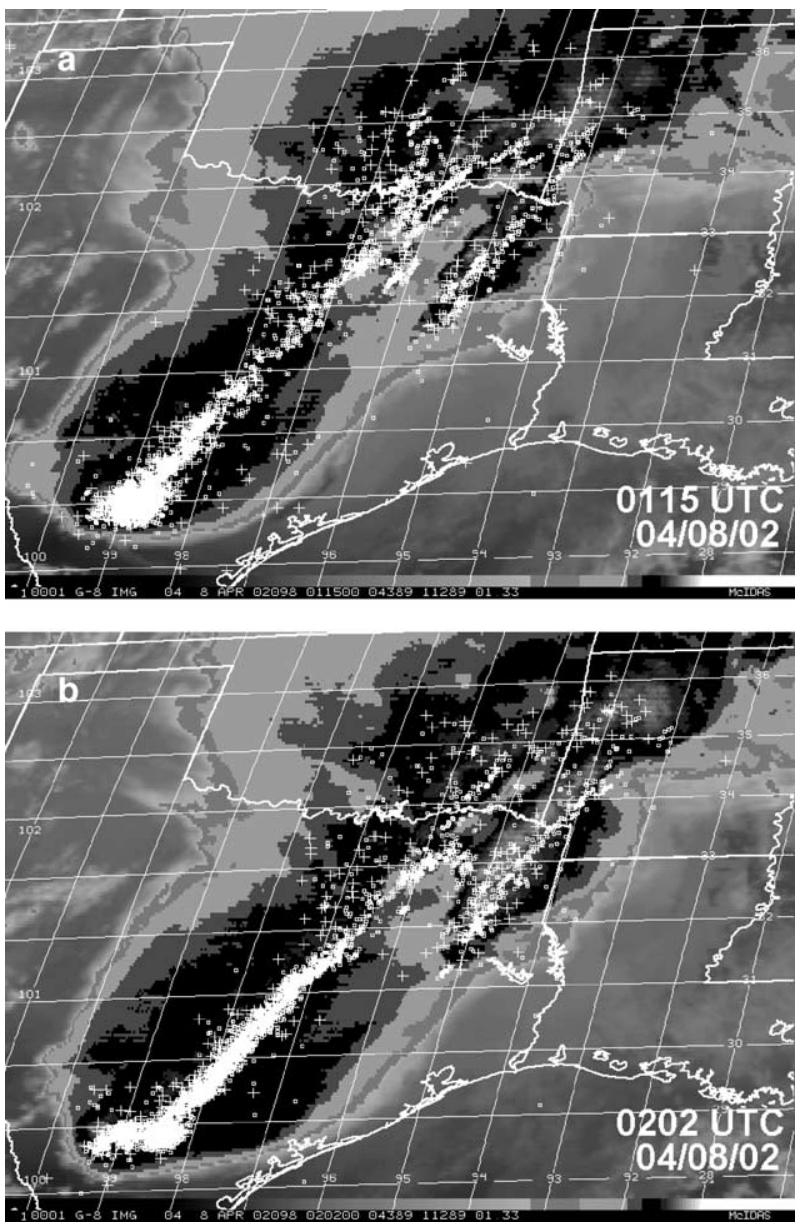

Fig. 12. As Fig. 10, but for 8 April, 0115 (a) and 0202 UTC (b), within the time frame of MCS passage through KFWS radar range (cf. Figs. 5f, 13 and 14).

spreading into smaller lines becomes more pronounced in southern Oklahoma where the MCS merges with the old stratiform precipitating system that had covered Oklahoma for most of the day on 7 April.

Note the coldest cloud tops over eastern Oklahoma at the Oklahoma-Arkansas border: Here are the remnants of the circular MCS that had formed in the Dallas-Ft. Worth region simultaneously with the Throckmorton storms, cf. Fig. 6b. There is a line of high cloud tops and CG lightning activity spreading south-southwestward from the OklahomaArkansas border into eastern Texas ahead of the LLTS MCS. As derived from the GOES East imagery, it was formed by convective initiation along two outflow boundaries: The one created by the circular Dallas-Ft. Worth MCS on its way to Oklahoma, and another, preexisting one south of Dallas-Ft. Worth, which is visible by moderately high clouds and weak lightning activity in Fig. 6. 
About 50 min later, Figs. $5 \mathrm{f}$ and $12 \mathrm{~b}$ at 0202 UTC show that the squall line features have become more distinct and the system is now more homogeneous. The southern part of the line still has the highest CG flash density and the shape of a symmetric MCS. In the northern, LLTS part of the MCS, the smaller-scale convective lines have merged to a large degree, so there is now one main leading line with a large trailing stratiform part containing many positive $\mathrm{CG}$ flashes from $32^{\circ} \mathrm{N}$ into southern Oklahoma. The separate convective line over eastern Texas is still present and has intensified as well. Its distance to the main LLTS MCS has decreased and, at a latitude of $33^{\circ} \mathrm{N}$, there appears to be a CG lightning "bridge" connecting the two lines.

Note that the coldest and likely highest cloud tops occur with this precursory convective line in eastern Texas, way up to northwest Arkansas where the remnants of the old Dallas-Ft. Worth circular MCS are. Another region of cold cloud tops is the southernmost tip of the main MCS.

We now focus on the Dallas-Ft. Worth region, where total lightning and radar data can be related to the NLDN and GOES 8 observations. The total (i.e., not segregated into convective or stratiform regions) LDAR II source number maximum at about 0045 UTC and its subsequent decrease preceded the total CG flash rate maximum and subsequent decline by about $30 \mathrm{~min}$ in this case (McCormick, 2003). Since initial lightning flashes within convection are IC discharges (Krehbiel, 1986), it is not surprising that these temporal trends became evident. A constant altitude plan position indicator (CAPPI) of KFWS radar reflectivity at $2.0 \mathrm{~km}$ AGL overlaid with 5-min NLDN-detected CG flash data for the LLTS MCS at 0119 UTC on 8 April is shown in Fig. 13a. Note that the image time is almost the same as for Fig. 12a. Most of the CG lightning flashes occur within the convective region, which is dominated by CG- flashes (e.g., Holle et al., 1994). Also apparent is the higher percentage of $\mathrm{CG}+$ flashes in the stratiform region as compared to the convective part (cf. Nielsen et al., 1994).
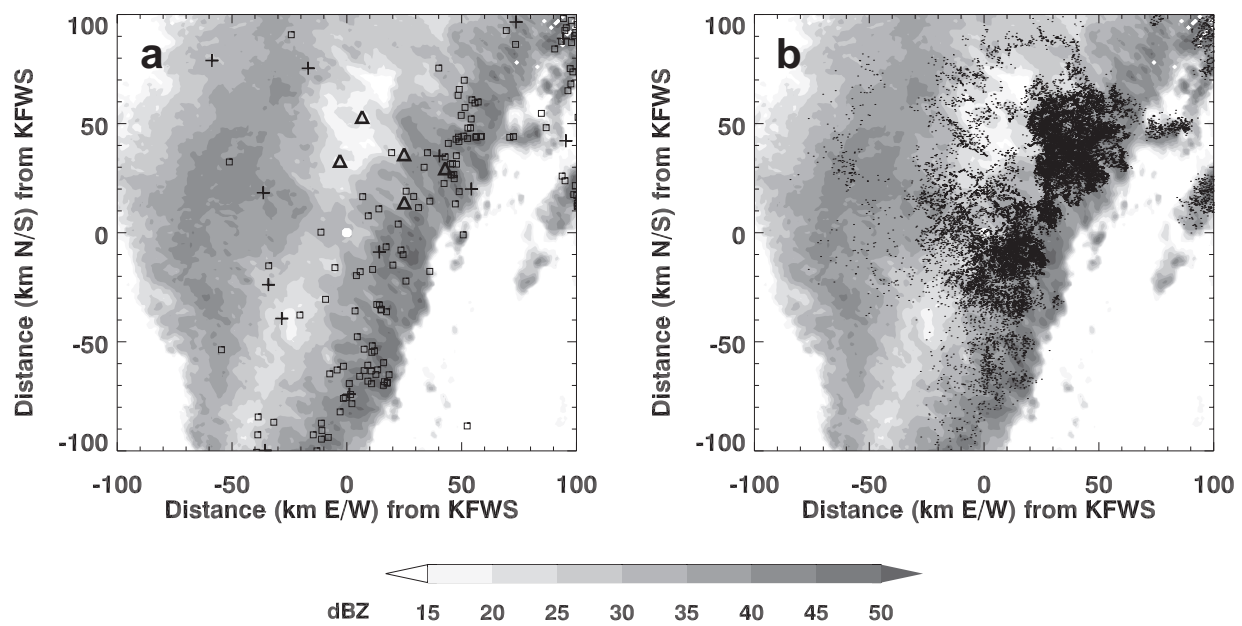

Fig. 13. KFWS $2.0 \mathrm{~km}$ AGL reflectivity CAPPI at 0119 UTC on 8 April. The radar is located in the origin. (a) NLDN 5 min CG flash overlay centered at radar volume time, $+=\mathrm{CG}^{+}, \square=\mathrm{CG}-$. LDAR II sensors are shown as $\triangle$-symbols. (b) LDAR II 5 min centered VHF signal overlay (30570 sources from 764 classified flashes). 
The CG + first stroke peak current in the stratiform region of tropical and mid-latitude MCSs was studied by Petersen and Rutledge (1992). They found a dominance of high (low) current CG+ flashes in the stratiform (convective) region of the storms. Lyons et al. (1998) discuss this and the results by Stolzenburg et al. (1994) in the context of in situ charging processes in the stratiform region of MCSs. For the early hours of 8 April 2002, when the MCS passed the Dallas-Ft. Worth area, McCormick (2003) was able to confirm these previous findings.

From 0000 to $0400 \mathrm{UTC}$, the 5-min average positive and negative CG first stroke currents were $35.0 \mathrm{kA}$ and $-20.7 \mathrm{kA}$, respectively. Peak positive current increased with the development of the stratiform region within the KFWS radar range around 0100 UTC. After the convective region had propagated beyond the radar range, another increase in positive peak current was evident at the end of the period when only the stratiform region was within view. Performing a radar-based segregation of convective and stratiform regions revealed that the 5-min average peak positive current in the stratiform region (43.0 kA) was over two times larger than the average peak positive current in the convective region $(20.2 \mathrm{kA})$. The 5-min average peak negative current in the stratiform region $(-22.3$ $\mathrm{kA}$ ), however, was only slightly larger than the average negative current in the convective region $(-20.2 \mathrm{kA})$.

Since the transition zone between the convective and stratiform regions likely lacks upward motions, ${ }^{5}$ the non-inductive charging mechanism is inefficient, and little or no CG lightning flashes are produced in this region. These trends are consistent throughout the period (0000 to 0400 UTC) during which the 7-8 April 2002 MCS with its LLTS part was within range of KFWS radar.

A sample of 5-min LDAR II VHF source locations relative to the $2.0 \mathrm{~km}$ AGL reflectivity CAPPI of the MCS at 0119 UTC is depicted in Fig. 13b. It is evident that increased numbers of VHF sources are located along the back half of the leading convective line where the mature-to-dissipating convective cells lay, and the leading edge of the stratiform region, since a sufficient amount of time is needed to build up enough electric charge within a convective cell to produce lightning flashes (Krehbiel, 1986). The leading edge of the stratiform region may be associated with increased LDAR II VHF source numbers as a result of either charge advection from the convective region (e.g., Rutledge and MacGorman, 1988) or an in situ charge generation mechanism (e.g., Engholm et al., 1990; Rutledge et al., 1990; Rutledge and Petersen, 1994; Zajac and Rutledge, 2001).

Line-normal vertical cross-sections of average radar reflectivity factor $Z$ and the total LDAR II VHF source density over 5-min intervals within the $200 \times 200 \times 20 \mathrm{~km}^{3} \mathrm{KFWS}$ radar volume have also been computed for the MCS on 8 April (Fig. 14). For the averaging, a $200 \mathrm{~km}$ long part of the squall line was used. Fig. 12 had shown evidence that the MCS indeed showed the LLTS characteristics over a distance of $\pm 100 \mathrm{~km}$ north and south of Dallas-Ft. Worth. As the MCS was apparently in a quasi-stationary or only weakly intensifying state at this time, it appears justified to give a composite of four individual snapshots $(0039,0104,0119$ and 0203 UTC, cf. Fig. 12) in Fig. 14 to get a

\footnotetext{
${ }^{5}$ Mass continuity requires subsidence next to the convective core of the MCS. As it is of LLTS type, this must be more pronounced on the rear side and can be related to the presence of a surface mesohigh as seen in Fig. 3c.
} 


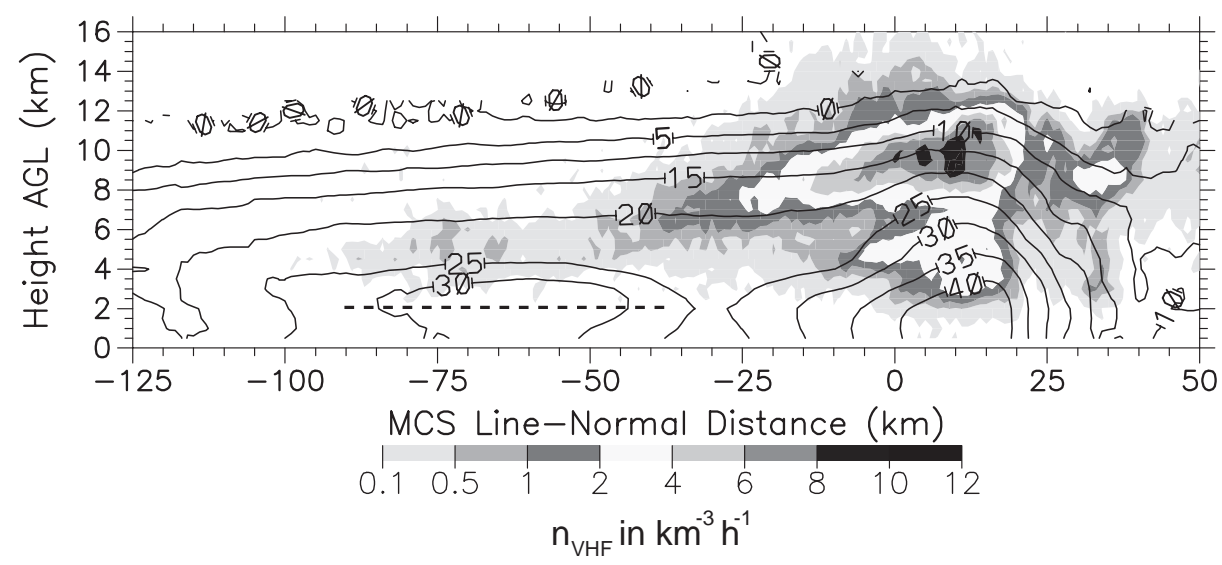

Fig. 14. Composite of four individual vertical line-normal cross sections of radar reflectivity factor and LDAR II source density $n_{\mathrm{VHF}}$ through the MCS as it passed the Dallas-Ft. Worth area at 0039, 0104, 0119 and 0203 UTC on 8 April. Isopleths: line-parallel $200 \mathrm{~km}$ spatial average of KFWS radar reflectivity factor. Grayscale shading: same spatial average for 5 min of LDAR II VHF source density given in $\mathrm{km}^{-3} \mathrm{~h}^{-1}$. Origin of storm-relative horizontal coordinate was defined by ground location of average rear flank $40 \mathrm{dBZ}$ contour.

more complete vision of radar reflectivity and total lightning activity. This provides the most reliable view on spatial VHF source distribution in the MCS despite the loss of LDAR II sensors $\mathrm{B}$ and $\mathrm{C}$, which resulted in decreased detection efficiency and likely caused some of the IC lightning evolution between the individual times.

At early times (0039 UTC), the LDAR II network did not observe flashes in the stratiform region above the melting layer. They were likely there, since the stratiform system was fairly steady the whole time and also because there were NLDN-detected CG discharges in the same region. At later times (0203 UTC), the reduced LDAR II network did not observe flashes in the convective leading line very well, particularly at low levels. At this time, the area beneath the melting layer was below the LDAR II field of view. Yet, there is evidence that IC flashes were still there, based on the presence of CG lightning activity revealed by the NLDN data. The times in between at 0104 and 0119 UTC show the least reduction in LDAR II detection performance.

Assuming stationarity of LLTS MCS kinematics, the procedure of giving a composite image of vertical distribution of LDAR II VHF sources versus KFWS radar reflectivity minimizes effects of reduced LDAR II detection efficiency and likely best documents MCS structure in the line-normal vertical frame of reference in Fig. 14. Within the convective line, there are two dominant electrically active VHF source layers apparent from this image: Consistent with the conceptual model of a tripole (Williams, 1989) in the leftmost schematic of Fig. 1, the lower dominant source region is centered at $4.5 \mathrm{~km}$ AGL (approximately $-5{ }^{\circ} \mathrm{C}$, derived from the 8 April, 0000 UTC Ft. Worth environmental sounding in Fig. 4c), a local minimum is centered at about $6.5 \mathrm{~km} \mathrm{AGL}\left(-20{ }^{\circ} \mathrm{C}\right)$, and the upper dominant VHF source region is centered at $10 \mathrm{~km} \mathrm{AGL}\left(-45^{\circ} \mathrm{C}\right)$. This upper dominant source region descends from the convective line into the trailing stratiform region, suggesting that the charge advection mechanism may take place here. The downward-sloping maximum in VHF sources behind the convective line was also shown 
by McCormick (2003) and Demetriades et al. (2004). The source region terminates at approximately 3.5 to $7 \mathrm{~km}$ AGL (roughly 0 to $-25^{\circ} \mathrm{C}$ ) just above the melting layer, being visible by the local reflectivity maximum or "bright band" (i.e., 2.5-3 km AGL or roughly consistent with the height of the $0{ }^{\circ} \mathrm{C}$ wet bulb temperature at $3.2 \mathrm{~km}$ AGL). Note that the melting layer signature (highlighted by a dashed line in Fig. 14) is significantly smeared in the vertical by the $1^{\circ} \times 1 \mathrm{~km}$ resolution of the KFWS WSR-88D data. Taking into account the MCS propagation of $60 \mathrm{~km}^{-1}$, the observed rate of descent of about $1.4 \mathrm{~m} \mathrm{~s}^{-1}$ in the slanted region is consistent with typical hydrometeor fallspeeds (e.g., for snow) in stratiform parts of thunderclouds. Another large VHF source concentration also exists ahead of the convective leading line within convective cells in the precursory line which was already identified in Fig. 12 to "bridge" into the LLTS MCS at the Dallas-Ft. Worth latitude of $33^{\circ} \mathrm{N}$.

The slanting lightning region terminates above the melting layer in the stratiform region, where horizontally layered VHF lightning sources occuring from 3.5 to $6.5 \mathrm{~km}$ AGL (about 0 to $-20{ }^{\circ} \mathrm{C}$ ) are clearly evident. The horizontally layered VHF lightning sources at these heights and temperatures are consistent with past in situ E-field measurements in the stratiform region, which inferred the presence of multiple, extensive charge layers above the melting layer (e.g., Marshall and Rust, 1993; Stolzenburg et al., 1994; Mo et al., 2003). This layered electrically active zone in the stratiform part could be further evidence of an in situ charging process occurring within the stratiform region (e.g., Engholm et al., 1990; Rutledge et al., 1990; Rutledge and Petersen, 1994).

Note that other such layered source regions were evident at some individual points in time. They are, however, hardly discernible in the composite of Fig. 14. For instance, at $0119 \mathrm{UTC}$, roughly 60 to $80 \mathrm{~km}$ behind the convective region between 8.5 and $11 \mathrm{~km}$ altitude, there was a region of weak layered VHF activity high in the trailing stratiform region (McCormick, 2003; Carey et al., 2003b). This additional discharge region was at a higher altitude than and did not seem to be connected to the main VHF source region that descended from the convective region and into the stratiform region. Therefore, this isolated electrically active zone at upper levels toward the rear portions of the stratiform zone (i.e., $60 \mathrm{~km}$ or more from the convective line) could be even stronger evidence of an in situ charging process also occurring within the stratiform region.

After passing the Dallas-Ft. Worth area, the lifecycle of this MCS was not yet finished. As Figs. 5g-i and 15 show, the evolution continued rather steadily. Fig. 15a at 0715 UTC on 8 April documents a single, well-defined line of high CG flash activity from the Gulf of Mexico coast to southern Arkansas. Only the part of the line forming the southernmost tip of the MCS in Fig. 12b has hardly advanced during these 5 -h period and stays over central southern Texas. But also in this part of the line, the MCS type has now changed to clear LLTS characteristics everywhere, cf. Fig. 5h,i. Many $\mathrm{CG}+$ flashes are visible in the now very large trailing stratiform part of the MCS. Interestingly, the coldest cloud tops now occur just behind the leading line of CG flash activity and most of the $\mathrm{CG}+$ discharges appear to be located in the center of this region of coldest, highest cloud tops. Note that these lowest cloud top brightness temperatures near $-70{ }^{\circ} \mathrm{C}$ are several degrees below the minimum $T_{\mathrm{B}}$ values observed 

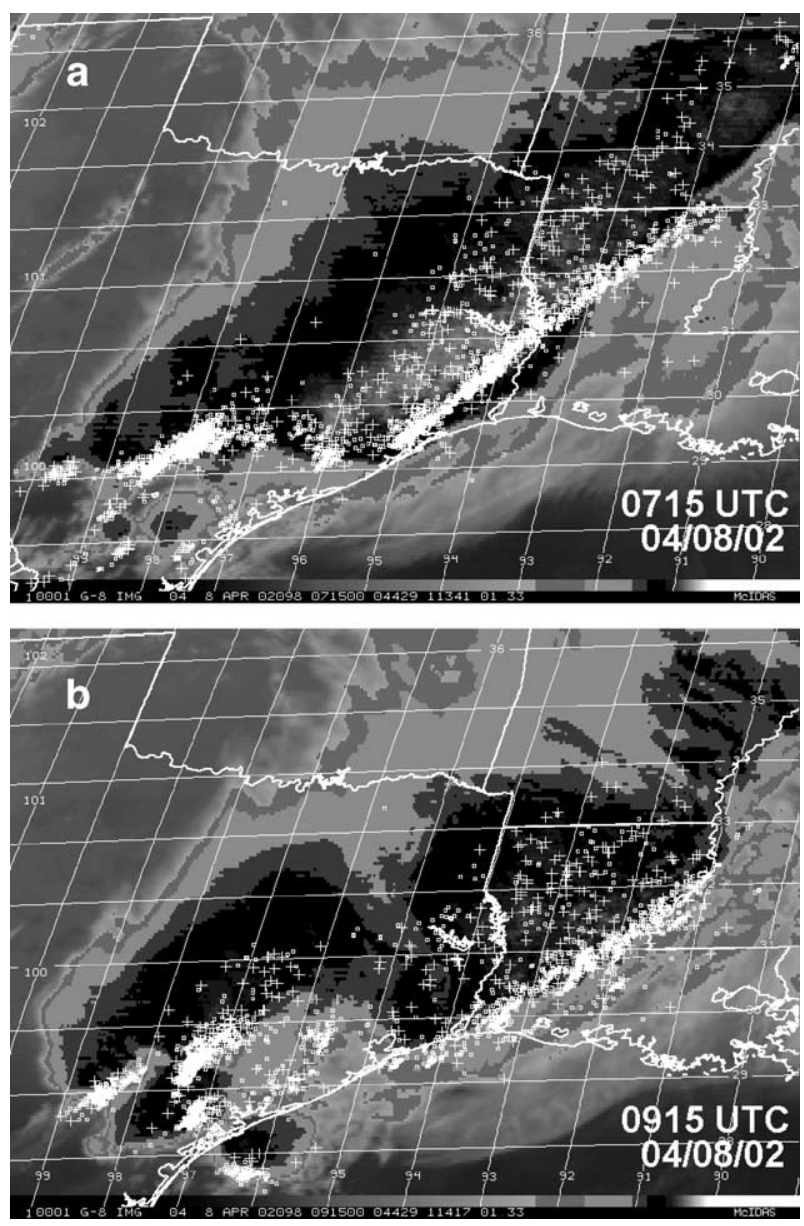

Fig. 15. As Fig. 12, but for 8 April, 0715 (a) and 0915 UTC (b). For (a), cf. Fig. 5h,i. In (b), the first signs of linear MCS decay become apparent.

in the Dallas-Ft. Worth region earlier from 0100 to 0200 UTC (cf. Fig. 12). Fig. 15b illustrates the first signs of a decay in this long-lived LLTS MCS at 0915 UTC on 8 April. The system now starts to disintegrate into a western and an eastern part and, in each of these, CG lightning activity begins to lose its linear character. Instead, there is a trend towards clustering of $\mathrm{CG}$ flashes into individual cells again. Minimum cloud top brightness temperatures are still below $-65{ }^{\circ} \mathrm{C}$, but not as low as $2 \mathrm{~h}$ before in Fig. 15a. One feature of the mature LLTS stage remains, however: The dominance of $\mathrm{CG}^{+}$flashes in the trailing stratiform regions of the cloud, especially in the newly separated eastern part of the MCS. After crossing the Gulf of Mexico coast, the system mainly propagated eastward along the coastline, degrading in size and intensity and acquiring a more elliptical shape of its cloud shield. However, well into 9 April, the now rapidly decaying MCS remained electrically active even at this very late stage of its evolution. 


\section{Discussion}

\subsection{Formation stage of the MCS and Throckmorton supercell}

The most striking features in the GOES East satellite images and the NLDN CG flash data during the formation of the MCS over Texas were the ring-like cloud top features observed at several locations along the developing squall line, and simultaneously the 15min oscillations of CG flash multiplicity, especially for the $\mathrm{CG}+$ discharges, in the storms around Throckmorton county.

The also observed V-shaped cumulonimbus overshoot of the Throckmorton supercell is known to be a characteristic of severe storms (Maddox, 1981; McCann, 1983; Adler et al., 1985; Heymsfield and Blackmer, 1988). However, features exactly like the several observed ring-like cloud top structures during MCS formation have rarely been depicted before (the exceptions being, e.g., Heymsfield et al., 1983a,b; Höller and Reinhardt, 1986). Other authors like Adler and Fenn (1979a,b) show similar structures, but on a smaller scale of approximately $50 \mathrm{~km}$ radius. Bartels and Maddox (1991) discuss smaller circular, but not ring-like, clusters of storm cells and the later formation of mid-level cyclonic vortices from these small MCCs. Heymsfield et al. (1983a,b) present results for internal warm areas in cumulonimbus anvils, yet mention these only in the context of individual storms, not clusters of them. So it appears as if further observations of developing squall lines were necessary to clarify if the ring-like cloud top features seen in the 7-8 April case are a relatively regular phenomenon under similar synoptic circumstances. Should this turn out to be the case, then these observations might be more systematically tested for their potential for severe weather early warning capability.

The Texas-Oklahoma region frequently experiences supercell thunderstorms and MCSs in spring and early summer (e.g., Goodman and MacGorman, 1986; Holle et al., 1994; Gilmore and Wicker, 2002). However, to the authors' knowledge, a similar phenomenon like the observed 15-min oscillation of CG flash multiplicity in the region of a number of severe storms, including a tornadic supercell and developing into a linear MCS, has not been reported before. While some researchers do not see physical reasons for the existence of multistroke $\mathrm{CG}^{+}$discharges at all (Mazur, 2002-personal communication; cf. also Zajac and Rutledge, 2001; Rakov and Huffines, 2003), they are nevertheless reported frequently, sometimes with even higher values for $\mathrm{CG}^{+}$ multiplicity as in the Throckmorton supercell (e.g., $n$-values up to 10 by Lyons et al., 1998). Here, we want to discuss the NLDN data in more detail and also present some options to explain this unexpected periodic behavior, based on currently available CG lightning detection methods.

The first such option to explain the surprising behavior of the $\mathrm{CG}+$ multiplicities would be "contamination" of the CG+ sample by weak discharges which could have been IC flashes really. The physical meaning of positive flashes below $10 \mathrm{kA}$ first return stroke peak current has been discussed by several authors before. Cummins et al. (1998) strongly claimed these weak CG+ lightning strikes to be IC flashes detected by the NLDN and suggested to remove them from any CG strike analysis. Others, like Lyons et al. (1998) discuss results indicating that these weak flashes might indeed mainly have been $\mathrm{CG}+$ and not IC discharges. This is supported by recent results of Betz et al. (2004) obtained from 
different lightning detection sensors than those of the NLDN: Their findings indicate that only about $40 \%$ of the weak CG + signals come from cloud regions aloft and should be classified as IC discharges. Clearly, as stated by Orville and Huffines (1999), and reiterated in a later publication (Orville et al., 2002): "Further research is needed on this issue". However, our available NLDN data contains only 24 weak CG+ with $I_{\max , 1}$ below $10 \mathrm{kA}$. So we can definitely exclude presence of many ambiguous weak $\mathrm{CG}+$ discharges in our case.

Mixed-polarity or bipolar flashes (Rakov, 2000) might also bias the segregation into $\mathrm{CG}+$ and $\mathrm{CG}-$ discharges. When looking at strokes in NLDN data (or in Europe the EUCLID data based on the same sensor types as in the NLDN), it can sometimes be seen that strokes of different polarity occur within a very small area (say, $10 \mathrm{~km}$ radius) within a short time period (say, $0.5 \mathrm{~s}$ ). If these are grouped into flashes by a radius/time criterion, then usually the first return stroke polarity is assigned as the overall flash polarity (and the first return stroke peak current is assigned as flash peak current). However, either assignment may not necessarily be adequate, as mentioned above for the peak currents already. For instance, a reevaluation of the CG stroke data of the German BLIDS network for the EULINOX supercell hailstorm investigated by Dotzek et al. (2001) revealed a small but significant portion of strokes closely clustered in space and time but with alternating polarity which could be grouped into mixed-polarity flashes by a simple radius/ time criterion.

Finally, another possible reason for the observed multiplicity oscillations might be a statistical sampling effect by which few $\mathrm{CG}+$ with high $n$-values ( $n$ up to 4 was observed with $\mathrm{CG}+$ in the selected sample of $\mathrm{CG}$ flashes) can dominate the 5-min ensembles of mainly unistroke $\mathrm{CG}+$ in the area of Fig. 10d. To clarify the influence of mixed-polarity flashes and sample size on our results, a reanalysis of the NLDN data contained in Fig. 10 was performed. It was based on the individual stroke data as originally recorded by the NLDN sensors and compared to results that would have arisen from the standard stroke-toflash algorithm.

The stroke data were segregated in the following way: Positive CG flashes with a small $\left(I_{\max , 1}<10 \mathrm{kA}\right)$ first stroke were separated from the rest of the positive flashes. Then the mixed-polarity CG flashes were distinguished by whether the first stroke was negative or positive. Moreover, the data were checked for very short interstroke intervals $(t<1 \mathrm{~ms})$ within all categories of flashes. Such short interstroke intervals can be due to effects like: (1) a separate group of sensors detected an ionospherically reflected signal and therefore produced a separate stroke location, or (2) the full group of sensors that detected one particular stroke was broken up somehow by the location algorithm and the two groups each produced a location for the same stroke. Finally, all small positive (again, $I_{\max , 1}<10 \mathrm{kA}$ ) subsequent strokes of multistroke CG discharges were looked up. Interestingly, all but one of these also had an interstroke interval of $t<1 \mathrm{~ms}$ relative to the preceding stroke.

In a second step, all of the CG strokes that met one of these criteria (interstroke interval below $1 \mathrm{~ms}$ or weak positive subsequent stroke) were removed and only then the stroke-toflash algorithm was applied. Afterwards, we reassessed whether the CG flashes were mixed-polarity, purely positive or purely negative. Multiplicities for flashes found to be purely positive or purely negative were also recalculated at this stage. 
The remaining mixed-polarity flashes were then excluded from the reanalysis, as a detailed analysis of mixed-polarity flashes is out of the realm of this LLTS MCS study. Clearly, this reanalysis procedure had a bigger impact on the $\mathrm{CG}+$ flash multiplicities than the simple removal of flashes with small positive first return strokes - the only action that could have been applied to the CG flash data generally used throughout this study.

Before the reanalysis, the flash data consisted of a total of 1711 CG flashes (1936 strokes) splitting into $534 \mathrm{CG}^{+}$and $1177 \mathrm{CG}-$ flashes. Of the $534 \mathrm{CG}+$ discharges, only 24 had small first return stroke currents of $I_{\max , 1}<10 \mathrm{kA}$, leaving 510 unambiguous $\mathrm{CG}+$ flashes. After reanalysis of the stroke data, the following numbers resulted: $487 \mathrm{CG}^{+}$ flashes with $I_{\max , 1}>10 \mathrm{kA}, 23$ weak CG+ flashes with $I_{\max , 1}<10 \mathrm{kA}$ and $1155 \mathrm{CG}-$ discharges. Of the 47 mixed-polarity flashes, 23 had a positive first return stroke and 24 had a negative first return stroke.

When comparing these reanalyzed data with the present Figs. 10 and 11, significant differences merely appear in the flash multiplicities, so Fig. 16 shows only these. Fig. 16a should be compared to Fig. 10b, and Fig. 16b corresponds to Fig. 11b. In general, the average multiplicities are lowered by the reanalysis procedure. Two things remain robust features in the data, however: (1) the average $\mathrm{CG}+$ multiplicities are higher than those of the CG - flashes, especially in Fig. 16a, and (2) the CG+ multiplicitiy in Fig. 16a still displays rather regular oscillations over the 4-h period from 1900 to 2300 UTC. In Fig. $16 \mathrm{~b}$, the sudden peak in $\mathrm{CG}+$ multiplicity shortly before the end of the tornadic phase is retained. The weaker secondary peak of $n$ visible in Fig. $11 \mathrm{~b}$ a few minutes before the tornadic phase is gone in the reanalyzed data. So for most of the tornadoes' lifetimes, the $\mathrm{CG}+$ flashes within $30 \mathrm{~km}$ range consist of only one stroke.

To sum up our stroke reanalysis, we can quantify that only 23 of the multistroke $\mathrm{CG}^{+}$ flashes on 7 April 2002 consisted of strokes with alternating polarity. As was the case for the weak $\mathrm{CG}+$ flashes with $I_{\max , 1}<10 \mathrm{kA}$, this small number does not significantly affect or bias our sample of CG discharges. However, the $\mathrm{CG}+$ ensemble is reduced by about $10 \%$ (534 $\mathrm{CG}+$ before, $487 \mathrm{CG}+$ after the reanalysis) due to subtraction of bipolar and weak $\mathrm{CG}+$ discharges.
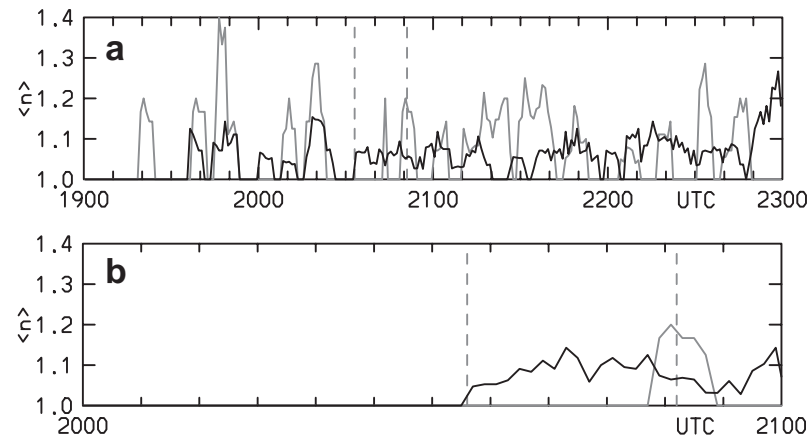

Fig. 16. Ground flash multiplicities $n$ (black $=\mathrm{CG}-$, gray $=\mathrm{CG}^{+}$) for the Throckmorton supercell region as in Figs. 10 and 11, but using the reanalyzed NLDN stroke data. Tornado period is marked by dashed vertical lines. Panel (a) based on 1642 CG flashes (487 CG+) corresponds to Fig. 10b. Panel (b) contains 185 CG flashes (32 $\mathrm{CG}^{+}$) and should be compared to Fig. 11b. 
Therefore, sample size remains as the only candidate for a technical reason to explain the $\mathrm{CG}+$ flash multiplicity oscillations. A sample size of about $500 \mathrm{CG}+$ is certainly marginal but not so small as to make an oscillatory sampling error like this very probable, also in light of the fact that the $\mathrm{CG}$ - flashes showed a similar, but less pronounced periodicity in the $n$-values. Besides, it would be a notable coincidence to have such a sampling error quite uniformly distributed over a 4-h time frame. Nevertheless, until 2100 UTC, the most CG+ flashes in any 5-min period is 10 and, after $2100 \mathrm{UTC}$, it rarely gets above 20. This is one reason for a certain noise level in the multiplicities for $\mathrm{CG}+$ flashes. The average $\mathrm{CG}+$ multiplicity in many 5 -min periods does exceed the average $\mathrm{CG}-$ multiplicity, however. We have to stress that the effects of the marginal sample size are alleviated by the fact that we have computed 5-min running means of all time series in Figs. 10 and 11. As we are dealing with a physically distinct phenomenon in our analysis (the electrical activity of the storms in the Throckmorton region), we cannot increase the data sample by simply enlarging the domain size or time frame without blurring the results by lightning activity from other, more distant storms. Instead, we have to settle for the available sample of NLDN-detected flashes.

However, as the use of NLDN CG stroke data provided much more insight than the preprocessed NLDN flash data in this special analysis, we can draw the following conclusion: For future scientific analyses of CG flash activity and storm evolution, in accordance with the discussion by Rakov and Huffines (2003), we think it is advisable to mainly rely on stroke data instead of preprocessed flashes, to be able to retrace any sampling effects which may arise from any stroke-to-flash algorithm.

Yet, aside from these more technical reasons, the $15-\min$ period of mainly $\mathrm{CG}+$ flash multiplicity might also be related to cloud physical effects. Assuming an overshooting cloud top height of 14-15 km in the early MCS formation stage, it becomes apparent that a time interval of about 15 min corresponds to the typical timescale of an air parcel ascending from the near surface inflow layer to the overshooting top. This would require an average updraft speed of $60 \mathrm{~km} \mathrm{~h}^{-1}$ or $17 \mathrm{~m} \mathrm{~s}^{-1}$. This number is reasonable for an average thunderstorm updraft velocity (which may have local peak values well above that). While surface parcels travel towards the storm tops in undiluted updrafts, the air at the anvil level is horizontally displaced by a similar distance, feeding new ice crystals into the downwind flank of the storms' cores and to the stratiform regions in the anvil (e.g., Danielsen, 1982).

This process of supplying fresh cloud liquid water to the storm (Saunders et al., 1991) in the updraft cores, and pristine ice crystals to the stratiform region (Baker et al., 1999), is continuous in the first place. The question then to clarify is why that process develops some periodicity, reflected by the 15-min oscillations in CG flash multiplicity. This may arise due to a pulsation of the storms' updrafts, and the reason for this pulsation could be a phenomenon of self-organization between the neighboring thundercells. Recall Figs. 6b, 7 and 8, which proved that the thunderstorms later merging into the northern part of the LLTS MCS were more or less circular aligned with typical distances of 20 to $30 \mathrm{~km}$. The region from which large storms draw their boundary layer inflow air has a comparable radius of influence. As soon as one storm's continuous supply of near-surface air is disturbed, for instance by the approaching outflow of another storm, a weakening and subsequent oscillation in updraft intensity can set in. This will then have a feedback on any nearby storm competing for the same boundary layer air "catchment", possibly initiating 
the self-organization required to lead to an oscillation in a whole ensemble of storms, with a repetition time related to the average timescale of an air parcel rising from the boundary layer to the storm's top. ${ }^{6}$

Based on the available data, we cannot make any clear judgement which of the above effects may have contributed most to the development of the oscillation in especially the $\mathrm{CG}+$ flash multiplicity. Yet we report this interesting and unexpected observation as a basis for future investigations of the lightning activity in similarly clustered stroms.

The close-up on the Throckmorton storm (cf. Fig. 11) revealed most of the CG+ flashes north of the tornadoes, supporting the concept of a tilted dipole as in Fig. 1 (cf. Rutledge et al., 1990; Hamlin et al., 2003). CG+ discharge multiplicity equaled 1 during most of the tornadoes' lifetime, and there were high positive first return stroke currents at the end of the tornadic phase. However, these were likely from the convective core of the storm, not from a stratiform part as in the MCS analysis by Petersen and Rutledge (1992). The CGmultiplicity was generally low compared to results by Rakov and Huffines (2003) and there was a minimum of CG flash rate about halfway into the tornadoes' lifetime.

This parallels observations of unusually low negative multiplicities approaching $n=1$ in some, mostly northern High Plains severe storms with an anomalously high (more than 25\%) CG+ percentage (Branick and Doswell, 1992; Curran and Rust, 1992; Lyons et al., 1998; Carey and Rutledge, 2003). Negative first return stroke current magnitudes in these cases were also typically low compared to regional climatological means (Orville et al., 2002), much alike in the Throckmorton supercell producing over $25 \% \mathrm{CG}+$ strikes for most periods and $\mathrm{CG}$ - first stroke currents relatively low compared to climatological annual (and warm season) median values in that part of Texas. While in this case the median of $I_{\max , 1}$ is about -12 to $-15 \mathrm{kA}$, more typical numbers averaged over all storms in the warm season would lie in the -20 to $-25 \mathrm{kA}$ range (MacGorman and Morgenstern, 1998).

What is called "anomalous" with thunderstorms certainly depends on region and season (cf. Seimon, 1993; Stolzenburg, 1994; Orville and Huffines, 2001; Lang et al., 2000; Lang and Rutledge, 2002). Based on earlier studies and climatological experience with lightning in severe storms (e.g., Reap and MacGorman, 1989; MacGorman and Burgess, 1994; Zajac and Rutledge, 2001; Carey et al., 2003a; Carey and Rutledge, 2003), these types of storms are probably only marginally anomalous over northern Texas during the month of April. Based on the work by Carey et al. (2003a), our estimate is that among all severe storms in this region, on average $10 \%$ to $30 \%$ or possibly a higher percentage may behave similar to the Throckmorton cell during spring, and we can say with some confidence that these types of storms do occur in northern Texas during the month of April in any given year. So the Throckmorton supercell appears to have been an anomalous storm only when compared to nationwide USA annual statistics.

\subsection{Mature LLTS stage of the MCS}

The 7-8 April 2002 MCS was a classic LLTS MCS while passing over the Dallas-Ft. Worth region. It provided an opportunity to study the radar and electrical evolution of the

\footnotetext{
${ }^{6}$ Note that this bears some resemblance to recently developed concepts concerning updraft regeneration in multicell convection, yet on a larger scale. See http://www.caps.ou.edu/ dweber/bubbles.html for an overwiew.
} 
convective and stratiform regions, even though the LDAR II network had decreased source detection efficiency because it was not operating at full capacity during this severe weather case.

McCormick (2003) demonstrated that the $\geq 30 \mathrm{dBZ}$ radar echo volume aloft between the 0 and $-40{ }^{\circ} \mathrm{C}$ temperature levels was larger and the rainfall rates were higher in the convective region than in the stratiform region of the LLTS MCS. These conditions indicate the presence of larger hydrometeors suspended by strong updrafts in mixed-phase microphysical conditions and provide some support for the noninductive charging mechanism in the convective line. Under normal conditions, large hydrometeors (at $T<-10{ }^{\circ} \mathrm{C}$ and in the presence of significant liquid water content) charge negatively in the convective region, and large aggregates (at $T<-10{ }^{\circ} \mathrm{C}$, in the presence of low liquid water content) charge positively in the stratiform region (e.g., Saunders et al., 1991), resulting in a predominance of CG- discharges in the convective line and $\mathrm{CG}^{+}$flashes in the stratiform region. Accordingly, large VHF lightning source densities were present in the convective region. Since the transition zone of an LLTS MCS generally lacks upward motions due to compensating subsidence for mass continuity reasons next to the convective core, the non-inductive charging mechanism is inefficient and little or no CG lightning flashes are produced in this region. Thus, the convective region was the dominant charging region present in this MCS, consistent with conceptual models and earlier lightning studies (e.g., Mazur and Rust, 1983; Rutledge and MacGorman, 1988).

Within the convective region of the 7-8 April 2002 MCS, two dominant lightning regions were detected by the LDAR II network in the vertical. Since negative polarity breakdown in the positive charge region is inherently noisier in the VHF band than positive polarity breakdown in the negative charge region, the two VHF source maxima and local minimum in between likely correspond to the three dominant charge regions of a tripole (Williams, 1989, leftmost sketch in Fig. 1) as follows: The upper positive charge region likely corresponds to the upper VHF source maximum (centered at $10 \mathrm{~km}$ AGL or about $-45^{\circ} \mathrm{C}$ ), the main negative charge region is likely centered on the relative minimum in VHF sources (centered at $6.5 \mathrm{~km}$ AGL or about $-20{ }^{\circ} \mathrm{C}$ ), and the lower positive region is likely associated with the lower VHF source maximum (centered at about $4.5 \mathrm{~km}$ AGL or $-5{ }^{\circ} \mathrm{C}$ ). This postulated tripole charge arrangement agrees with past observational results based on lightning measurements (Williams, 1989), the theory of non-inductive charging (e.g., Saunders et al., 1991) and the charge breakdown processes within the VHF range. As observed, predominantly $\mathrm{CG}$ - lightning flashes are generally produced from this tripole charge arrangement as illustrated in Fig. 1.

Within the stratiform region of the 7-8 April 2002 MCS, both NLDN and LDAR II lightning flash rates showed similar temporal trends and also resembled the evolution of the $\geq 30 \mathrm{dBZ}$ radar echo volume aloft between the -10 and $-40{ }^{\circ} \mathrm{C}$ temperature levels throughout the period (McCormick, 2003). Her radar echo volume analysis was consistent with a precipitation-based charging mechanism, which was likely tied to snow (or aggregates of ice crystals). So the observed correlation suggests that the presence of these larger ice aggregates or snow (i.e., $>30 \mathrm{dBZ}$ ) due to differential sedimentation in this temperature range was critical for electrification within the stratiform region via either charge advection or in situ charging. 
Within the stratiform region, one sloping primary active charge layer was detected by the LDAR II network. This charge layer appears to have been advected from the upper (positive) charge layer of the convective region into the stratiform region. The charge region slopes downward from upper levels $(\simeq 10 \mathrm{~km} \mathrm{AGL})$ within the convective line to low altitudes of about 3.5 to $7 \mathrm{~km} \mathrm{AGL}$ at the leading edge of, and well into, the stratiform region, corresponding to 0 to $-25{ }^{\circ} \mathrm{C}$ within this stratiform part of the MCS. Above the melting layer, a combination of an in situ process and charge advection may explain the formation of the layered charge structure from 3.5 to $6 \mathrm{~km}$ AGL $\left(0\right.$ to $\left.-20{ }^{\circ} \mathrm{C}\right)$. Note that Carey et al. (2005) did find mean upward motion above the melting layer in the stratiform region using a pseudo-dual-Doppler technique on KFWS data, so cloud water was likely available for non-inductive charging also. Given past modeling and laboratory results, there might not be a strong primary role for an inductive charging mechanism with ice-ice interactions and it does not seem like there would be enough ice-water interactions to make a difference given low liquid water content. However, there are other precipitation(or snow-) based charging mechanisms that could be operative in the stratiform region. For example, charge layers found at or near $0{ }^{\circ} \mathrm{C}$ have been observed in several balloon-borne E-field studies (e.g., Shepherd et al., 1996). Therefore, these layers may very well be associated with melting of snow and not non-inductive charging. The 16 June case shows layering of lightning (and hence charge) between 7 and $-3{ }^{\circ} \mathrm{C}$ in the stratiform region. This is likely not due to non-inductive charging.

Again, as negative polarity breakdown in the positive charge region is an efficient producer of VHF sources, their horizontally extended maximum above the melting layer is likely associated with net positive charge. Fig. 14 had revealed that this positive space charge is connected with the advection and sedimentation of the positively charged hydrometeors from the upper parts of the convective region. So it is unlikely that this positive charge can be attributed to a lower positive charge layer as proposed in the tripole model (cf. Fig. 1). As a result, presence of an inverted dipole in the stratiform region becomes the most likely explanation for the observed VHF source structure and the large percentage of $\mathrm{CG}^{+}$flashes from the trailing stratiform region. Another charge layer at greater heights ( 8.5 to $11 \mathrm{~km}$ AGL) that is spatially distinct from the other zones is likely best explained by in situ charging. With the absence of strong vertical motions, the stratiform region was an ineffective charge producer. Therefore, the relatively low observed lightning flash rates are consistent with theory.

Within the 16 June 2002 LLTS MCS observed by the same LDAR II network, Carey et al. (2005) found generally similar patterns in the line-normal structure of VHF lightning sources: (1) two active VHF zones in the convective region at similar heights, (2) a slanting and descending lightning zone from the top of the convection rearward to the melting layer in the stratiform region, and (3) horizontal layers of VHF sources above the melting layer at similar heights. Since all seven sensors were operational on 16 June, the general consistency gives us confidence in our results for this study. Specific differences between the cases occurred over the stratiform region where the LDAR II network on 16 June 2002 was able to consistently resolve two to three horizontal layers at 4.5, 6-6.5 and 8.5-9 km (Carey et al., 2005). Assuming these are positive charge layers as before, the results by Carey et al. (2005) are strikingly similar to the inferred positive charge regions from the E-field balloon observations of Marshall and Rust (1993) in a symmetric LLTS 
MCS. Because of the decreased detection efficiency of the LDAR II for the 7-8 April 2002 MCS, the lower two horizontal layers may be merged into one thick layer and the upper layer was less frequently observed.

\section{Conclusions}

Comparison of total lightning activity with Doppler radar and geostationary satellite observations of the 7-8 April 2002 MCS showed the following lightning characteristics coupled to storm evolution from isolated supercells to a large linear MCS with trailing stratiform region:

- Satellite images revealed several ring-like cloud top structures with a diameter of about $100 \mathrm{~km}$ after the first $3 \mathrm{~h}$ of MCS formation, prior to tornado genesis in the storms.

- The Throckmorton supercell was characterized by a V-shaped cloud top overshoot, high $\mathrm{CG}+$ percentage and low average $\mathrm{CG}-$ first stroke current and flash multiplicity. Together with the downshear shift of $\mathrm{CG}^{+}$discharges, these observations point to presence of a tilted dipole in the storm.

- Mainly $\mathrm{CG}+$, but also $\mathrm{CG}-$ average flash multiplicity in the Throckmorton tornadic supercell showed rather uniform oscillations with an estimated period of about $15 \mathrm{~min}$. This new result, however, needs further verification in future case studies, due to the marginal sample of flashes produced by this storm.

- In the mature MCS, the radar versus lightning activity comparison revealed two dominant discharge regions at the back of the convective leading edge, and a gentle descent of the upper discharge region into the trailing stratiform region, apparently coupled to hydrometeor sedimentation. $\mathrm{CG}+$ flashes from the stratiform region had high first return stroke peak currents.

- There were indications of possible in situ charging processes in the trailing stratiform part of the mature MCS well behind the transition zone and above the melting layer. Also, the integration of LDAR II and WSR-88D radar data yielded some evidence for an inverted dipole in the stratiform region of this LLTS MCS.

- From our analysis of CG flash activity and storm evolution, it proved more efficient and advisable to rely on individual return stroke data instead of segregated flashes.

Aside from 3D total lightning in MCSs, future studies could couple more operationally available NLDN observations of various severe storm types with radar and geostationary satellite data. This would reveal if regular oscillations in CG flash multiplicity or ring-like cloud top structures were frequent phenomena or just peculiarities of the MCS chosen here.

\section{Acknowledgments}

This work was initiated while the first author was on leave on a DLR-Forschungssemester grant at the NOAA-National Severe Storms Laboratory from 16 March 
to 17 June 2002. The authors are grateful to the two anonymous referees for their thoughtful reviews and to Chuck Doswell for his comments on an earlier version of the manuscript. John Masssura (USAF) and Darrin Hansing (NOAA-NWS) kindly shared their synoptic analysis of the relevant storm formation processes and provided the KDYX radar scans. Thanks to Thorsten Fehr for reevaluating the BLIDS CG stroke data of the 21 July 1998 EULINOX supercell hailstorm. Composite radar images were provided by Weather Services International Corp. (WSI) and NASA though the Global Energy and Water Cycle Experiment Continental-Scale International Project (GCIP). Sounding data courtesy of University of Wyoming.

\section{Appendix A. LDAR II network performance on 7-8 April 2002}

The LDAR II system detects pulses of VHF radiation ("sources") produced by the electrical breakdown processes of lightning in a $5 \mathrm{MHz}$ band currently centered between 61 and $64 \mathrm{MHz}$. The VHF sources are used to reconstruct the propagation of individual IC or CG flashes in three dimensions with a time-of-arrival procedure (cf. MacGorman and Rust, 1998; Rakov and Uman, 2003).

The detection efficiency of the LDAR II system can be estimated from the sensor characteristics and the distribution of radiated signals, which in this case are source powers. Source power estimates from another VHF time-of-arrival system, the New Mexico Tech Lightning Mapping Array (Rison et al., 1999; Krehbiel et al., 2002), have been presented by Thomas et al. (2001). The source power distribution and sensor characteristics are used to produce a flash detection efficiency estimate for the individual VHF sources. To do so, we assume that each flash produces 50 sources, a rather conservative number given the results of Boccippio et al. (2001b). We further assume that at least two sources must be detected before we acknowledge the flash. Using this method with the five sensors that were functioning during the 7-8 April 2002 storms, we estimate a flash detection efficiency of $60 \%$ within the perimeter of the network and $20 \%$ at a distance of $120 \mathrm{~km}$ from Dallas-Ft. Worth international airport.

For an exemplary altitude of $7.5 \mathrm{~km}$ AGL, Fig. 17a shows how the loss of the northern and northeastern Dallas-Ft. Worth LDAR II sensors B and C led to decreased lightning flash detection efficiency from over $90 \%$ (typical value) to $60 \%$ within the ring formed by the network's six peripheral sensors and from approximately $90 \%$ (typical value) to about $20 \%$ at a $120 \mathrm{~km}$ range from the network's central sensor. Note that the flash detection efficiency is relatively insensitive to altitude unless all sources in the flash are below about $3 \mathrm{~km} \mathrm{AGL}$, and except for the radio horizon effect at larger ranges. For the 7-8 April case, however, the detection efficiency is not good enough for this effect to show up: It is already approaching zero before reaching the radio horizon. Fig. 17b depicts the location accuracy of the reduced LDAR II network. The location accuracy values does not change greatly from 100 to $200 \mathrm{~m}$ near the center of the 5 -sensor network and up to $4 \mathrm{~km}$ at distances of about $120 \mathrm{~km}$ from the 5-sensor LDAR II network center, depending on azimuth: Compared to the detection efficiency in Fig. 17a, the location accuracy isopleths show a more notable deformation due to the loss of sensors $\mathrm{B}$ and $\mathrm{C}$ in the period of 7-8 April 2002. Note that the axis of smallest location accuracy deformation corresponds very 

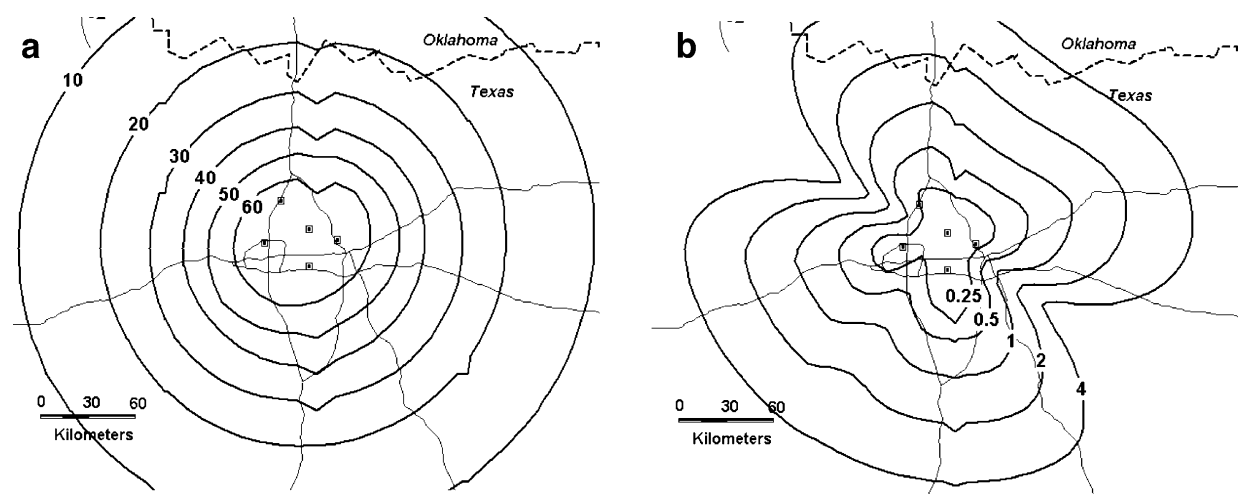

Fig. 17. Average values of (a) detection efficiency in $\%$ and (b) location accuracy in $\mathrm{km}$ at a height of $7.5 \mathrm{~km}$ AGL for the reduced Dallas-Ft. Worth LDAR II network with only five operational sensors ( $\square$ ) on 7-8 April 2002. The non-operational northern and northeastern sensors B and C are not depicted (cf. Fig. 2).

well with the line-parallel direction of the 7-8 April 2002 MCS. Due to this coincidence, the effects of reduced location accuracy on the interpretation of our MCS total lightning observations are minimized.

As discussed in detail by Rison et al. (2001), it is normally preferable to require that at least six sensors contribute to every source location in order to minimize the probability that local noise at one site might correlate accidentally and contribute to a false source location. Of course, it was not possible to use this requirement in the Dallas-Ft. Worth network for the 7-8 April storms. To minimize the effects of the occasional false positions that result when only five sensors are used to determine source locations, we utilized a data filtering procedure that involved eliminating sources that were relatively isolated. This filter varied as a function of range. Within $80 \mathrm{~km}$ of the center of the Dallas-Ft. Worth network, any source location that did not have at least one other source within $3 \mathrm{~km}$ in the horizontal, $4 \mathrm{~km}$ in the vertical and $200 \mathrm{~ms}$ in time was removed from the data after all locations were calculated. Beyond $80 \mathrm{~km}$, any source location that did not have at least one other source within $15 \mathrm{~km}$ in the horizontal, $20 \mathrm{~km}$ in the vertical and $500 \mathrm{~ms}$ in time was removed from the data. This procedure is likely to have little effect on flash detection efficiency because a typical flash produces a large number of sources.

\section{References}

Adler, R.F., Fenn, D.D., 1979a. Thunderstorm intensity as determined from satellite data. J. Appl. Meteorol. 18, $502-517$.

Adler, R.F., Fenn, D.D., 1979b. Thunderstorm vertical velocities estimated from satellite data. J. Atmos. Sci. 36, $1747-1754$.

Adler, R.F., Mack, R.A., 1986. Thunderstorm cloud top dynamics as inferred from satellite observations and a cloud top parcel model. J. Atmos. Sci. 43, 1945-1960.

Adler, R.F., Markus, M.J., Fenn, D.D., 1985. Detection of severe Midwest thunderstorms using geosynchronous satellite data. Mon. Weather Rev. 113, 769-781. 
Baker, M.B., Blyth, A.M., Christian, H.J., Latham, J., Miller, K.L., Gadian, A.M., 1999. Relationships between lightning activity and various thundercloud parameters; satellite and modelling studies. Atmos. Res. 51, $221-236$.

Bartels, D.L., Maddox, R.A., 1991. Midlevel cyclonic vortices generated by mesoscale convective systems. Mon. Weather Rev. 119, 104-118.

Betz, H.-D., Schmidt, K., Oettinger, P., Wirz, M., 2004. Lightning detection with 3-D discrimination of intracloud and cloud-to-ground discharges. Geophys. Res. Lett. 31, L11108.

Boccippio, D.J., Cummins, K.L., Christian, H.J., Goodman, S.J., 2001a. Combined satellite- and surface-based estimation of the intracloud-cloud-to-ground lightning ratio over the continental United States. Mon. Weather Rev. 129, 108-122.

Boccippio, D.J., Heckman, S.J., Goodman, S.J., 2001b. A diagnostic analysis of the Kennedy Space Center LDAR network: 1. Data characteristics. J. Geophys. Res. 106D, 4769-4786.

Branick, M.L., Doswell, C.A., 1992. An observation of the relationship between supercell structure and lightning strike polarity. Weather Forecast. 7, 143-149.

Brook, M., Nakano, N., Krehbiel, P., Takeuti, T., 1982. The electrical structure of the Hokuriku winter thunderstorms. J. Geophys. Res. 87, 1207-1215.

Carey, L.D., Rutledge, S.A., 1996. A multiparameter radar case study of the microphysical and kinematic evolution of a lightning producing storm. Meteor. Atmos. Phys. 59, $33-64$.

Carey, L.D., Rutledge, S.A., 1998. Electrical and multiparameter radar observations of a severe hailstorm. J. Geophys. Res. 103D, 13979-14000.

Carey, L.D., Rutledge, S.A., 2000. On the relationship between precipitation and lightning in tropical island convection: a C-band polarimetric radar study. Mon. Weather Rev. 128, 2687-2710.

Carey, L.D., Rutledge, S.A., 2003. Characteristics of cloud-to-ground lightning in severe and nonsevere storms over the central United States from 1989-1998. J. Geophys. Res. 108 (D15), 4483.

Carey, L.D., Rutledge, S.A., Petersen, W.A., 2003a. The relationship between severe storm reports and cloudto-ground lightning polarity in the contiguous United States from 1989 to 1998. Mon. Weather Rev. 131, 1211-1228.

Carey, L.D., McCormick, T.L., Murphy, M.J., Demetriades, N.W.S., 2003b. Three-dimensional radar and total lightning structure of mesoscale convective systems. Preprints. 31st Conf. on Radar Meteorol. Amer. Meteor. Soc, Seattle, pp. 80-83.

Carey, L.D., Murphy, M.J., McCormick, T.L., Demetriades, N.W.S., 2005. Lightning location relative to storm structure in a leading-line, trailing-stratiform mesoscale convective system. J. Geophys. Res. 110, D03105.

Cummins, K.L., Murphy, M.J., Bardo, E.A., Hiscox, W.L., Pyle, R.B., 1998. A combined TOA/MDF technology upgrade of the U.S. National Lightning Detection Network. J. Geophys. Res. 103D, 9035-9044.

Curran, E.B., Rust, W.D., 1992. Positive ground flashes produced by low-precipitation thunderstorms in Oklahoma on 26 April 1984. Mon. Weather Rev. 120, 544-553.

Danielsen, E.F., 1982. A dehydration mechanism for the stratosphere. Geophys. Res. Lett. 9 (6), $605-608$.

Defer, E., 1999. Caractérisation et modélisation de l'activité électrique de nuages dórage, (Characterization and modeling of thunderstorm electrical activity). PhD thesis (in French), Univ. Paris VII, 233 pp.

Demetriades, N.W.S., Murphy, M.J., 2003. Normal polarity severe thunderstorms dominated by negative CG lightning in the Dallas-Fort Worth area. Preprints. 12th Int. Conf. on Atmos. Elec., 9-13 June 2003, Versailles, pp. 47-50.

Demetriades, N.W.S., Murphy, M.J., Cummins, K.L., 2002a. Early results from the Global Atmospherics, Inc. Dallas-Fort Worth Lightning Detection and Ranging (LDAR II) research network. Preprints. 6th Symposium on Integrated Observing Systems, 13-17 January 2002, Orlando, pp. 202-209.

Demetriades, N.W.S., Murphy, M.J., Holle, R.L., 2002b. Lightning Detection and Ranging (LDAR II): results from Global Atmospherics, Inc. Dallas-Fort Worth research network. Preprints. 10th Conference on Aviation, Range, and Aerospace Meteorology, 13-16 May 2002, Portland. Amer. Meteor. Soc., Boston, pp. $245-248$.

Demetriades, N.W.S., Murphy, M.J., Holle, R.L., 2004. The importance of total lightning in the future of weather nowcasting. Preprints. Symposium on Planning, Nowcasting, and Forecasting in the Urban Zone, 11-15 January 2004, Seattle, Amer. Meteor. Soc., Boston. 9 pp. 
Dotzek, N., Höller, H., Théry, C., Fehr, T., 2001. Lightning evolution related to radar-derived microphysics in the 21 July 1998 EULINOX supercell storm. Atmos. Res. 56, 335-354.

Dotzek, N., Rabin, R.M., MacGorman, D.R., Demetriades, N.W.S., Holle, R.L., 2003. Lightning evolution in the severe storms in Texas on 7 April 2002. Preprints. 12th Int. Conf. on Atmos. Elec., 9-13 June 2003, Versailles, pp. 87-90.

Engholm, C.D., Williams, E.R., Dole, R.M., 1990. Meteorological and electrical conditions associated with positive cloud-to-ground lightning. Mon. Weather Rev. 118, 470-487.

Fehr, T., Dotzek, N., Höller, H., this volume. Comparison of lightning activity and radar-retrieved microphysical properties in EULINOX storms. Atmos. Res. doi:10.1016/j.atmosres.2004.11.027.

Fritsch, J.M., Forbes, G.S., 2001. Mesoscale convective systems. Meteor. Monogr. 28 (50), $323-357$.

Gilmore, M.S., Wicker, L.J., 2002. Influences of the local environment on supercell cloud-to-ground lightning, radar characteristics, and severe weather on 2 June 1995. Mon. Weather Rev. 130, 2349-2372.

Goodman, S.J., MacGorman, D.R., 1986. Cloud-to-ground lightning activity in mesoscale convective complexes. Mon. Weather Rev. 114, 2320-2328.

Hamlin, T., Krehbiel, P.R., Thomas, R.J., Rison, W., Harlin, J., 2003. Electrical structure and storm severity inferred by 3-D lightning mapping observations during STEPS. Preprints, 12th Int. Conf. on Atmos. Elec., 9-13 June 2003, Versailles, pp. 189-192.

Hane, C.E., Rabin, R.M., Crawford, T.M., Bluestein, B.B., Baldwin, M.E., 2002. A case study of severe storm development along a dryline within a synoptically active environment: Part II. Multiple boundaries and convective initiation. Mon. Weather Rev. 130, 900-920.

Heymsfield, G.M., Blackmer, R.H., 1988. Satellite-observed characteristics of Midwest thunderstorm anvils. Mon. Weather Rev. 116, 2200-2224.

Heymsfield, G.M., Blackmer, R.H., Schotz, S., 1983a. Upper-level structure of Oklahoma tornadic storms on 2 May 1979: I. Radar and satellite observations. J. Atmos. Sci. 40, 1740-1755.

Heymsfield, G.M., Szejwach, G., Schotz, S., Blackmer, R.H., 1983b. Upper-level structure of Oklahoma tornadic storms on 2 May 1979: II. Proposed explanation of "V" pattern and internal warm region in infrared observations. J. Atmos. Sci. 40, 1756-1767.

Holle, R.L., Watson, A.I., López, R.E., MacGorman, D.R., Ortiz, R., 1994. The life cycle of lightning and severe weather in a 3-4 June 1985 PRE-STORM mesoscale convective system. Mon. Weather Rev. 122, $1798-1808$.

Höller, H., Reinhardt, M.E., 1986. The Munich hailstorm of July 12, 1984: convective development and preliminary hailstone analysis. Contrib. Atmos. Phys. 59, 1-12.

Houze, R.A., 1993. Cloud dynamics. Int. Geophys. Ser., vol. 53. Acad. Press, San Diego. 570 pp.

Kane, R.J., 1991. Correlating lightning to severe local storms in the northeastern United States. J. Atmos. Sci. 46, $221-250$.

Keighton, S.J., Bluestein, H.B., MacGorman, D.R., 1991. The evolution of a severe mesoscale convective system: cloud-to-ground lightning location and storm structure. Mon. Weather Rev. 119, $1533-1556$.

Krehbiel, P.R., 1986. The electrical structure of thunderstorms. The Earth's Electrical Environment, Studies in Geophys. National Acad. Press, pp. 90-113.

Krehbiel, P., Thomas, R., Rison, W., Hamlin, T., Harlin, J., Davis, M., 2000. Lightning mapping observations in central Oklahoma. EOS 81 (3), 21-25.

Krehbiel, P., Hamlin, T., Zhang, Y., Harlin, J., Thomas, R., Rison, W., 2002. Three-dimensional total lightning observations with the lightning mapping array. Preprints. Int. Lightning Detection Conf., 16-18 October 2002, Tucson, Vaisala, Tucson. 6 pp.

Lang, T.J., Rutledge, S.A., 2002. Relationships between convective storm kinematics, precipitation, and lightning. Mon. Weather Rev. 130, 2492-2506.

Lang, T.J., Rutledge, S.A., Dye, J.E., Venticinque, M., Laroche, P., Defer, E., 2000. Anomalously low negative cloud-to-ground lightning flash rates in intense convective storms observed during STERAO-A. Mon. Weather Rev. 128, 160-173.

Lyons, W.A., Uliasz, M., Nelson, T.E., 1998. Large peak current cloud-to-ground lightning flashes during the summer months in the contiguous United States. Mon. Weather Rev. 126, 2217-2233. 
Lyons, W.A., Nelson, T.E., Williams, E.R., Cummer, S.A., Stanley, M.A., 2003. Characteristics of spriteproducing positive cloud-to-ground lightning during the 19 July 2000 STEPS mesoscale convective systems. Mon. Weather Rev. 131, 2417-2427.

MacGorman, D.R., 1993. Lightning in tornadic storms. Geophys. Monogr. 79, 173-182.

MacGorman, D.R., Burgess, D.W., 1994. Positive cloud-to-ground lightning in tornadic storms and hailstorms. Mon. Weather Rev. 122, $1671-1697$.

MacGorman, D.R., Morgenstern, C.D., 1998. Some characteristics of cloud-to-ground lightning in mesoscale convective systems. J. Geophys. Res. 103 (D12), 14011-14023.

MacGorman, D.R., Nielsen, K.E., 1991. Cloud-to-ground lightning in a tornadic storm on 8 May 1986. Mon. Weather Rev. 119, 1557-1574.

MacGorman, D.R., Rust, W.D., 1998. The Electrical Nature of Storms. Univ. Press, Oxford. 422 pp.

MacGorman, D.R., Burgess, D.W., Mazur, V., Rust, W.D., Taylor, W.L., Johnson, B.C., 1989. Lightning rates relative to tornadic storm evolution on 22 May 1981. J. Atmos. Sci. 46, $221-250$.

MacGorman, D.R., Rust, D., van der Velde, O., Askelson, M., Krehbiel, P., Thomas, R., Rison, B., Hamlin, T., Harlin, J., 2003. Lightning relative to precipitation and tornadoes in a supercell storm. Preprints. 12th Int. Conf. on Atmos. Elec., 9-13 June 2003, Versailles, pp. 203-206.

Maddox, R.A., 1980. Mesoscale convective complexes. Bull. Am. Meteorol. Soc. 61, 1374-1387.

Maddox, R.A., 1981. Satellite depiction of the life cycle of a mesoscale convective complex. Mon. Weather Rev. $109,1583-1586$.

Markowski, P.M., 2002. Hook echoes and rear-flank downdrafts: a review. Mon. Weather Rev. 130, $852-876$.

Marshall, T.C., Rust, W.D., 1993. Two types of vertical electrical structures in stratiform precipitation regions of mesoscale convective systems. Bull. Am. Meteorol. Soc. 74, 2159-2170.

Massura, J., Hansing, D., 2003. The importance of satellite imagery in boundary identification: The 07 April 2002 Throckmorton tornado. 7th Ann. NWA Severe Storms and Doppler Radar Conference, Des Moines, 27-29 March 2003.

Mazur, V., Rust, W.D., 1983. Lightning propagation and flash density in squall lines as determined with radar. J. Geophys. Res. 88D, 1495-1502.

McCann, D.W., 1983. The enhanced-V: a satellite observable severe storm structure. Mon. Weather Rev. 111, $887-894$

McCormick, T.L., 2003. Three-dimensional radar and total lightning characteristics of mesoscale convective systems. M.S. thesis, Dept. of Marine, Earth, and Atmos. Sci., North Carolina State Univ., 354 pp. [Available online at www.lib.ncsu.edu/theses/available/etd-08042003-035751/].

Mo, Q., Detwiler, A.G., Hallet, J., Black, R., 2003. Horizontal structure of the electric field in the stratiform region of an Oklahoma mesoscale convective system. J. Geophys. Res. 108 (D7), 4225.

Nielsen, K.E., Maddox, R.A., Vasiloff, S.V., 1994. The evolution of cloud-to-ground lightning within a portion of the 10-11 June 1985 squall line. Mon. Weather Rev. 122, 1809-1817.

Orville, R.E., Huffines, G.R., 1999. Lightning ground flash measurements over the contiguous United States: 1995-97. Mon. Weather Rev. 127, 2693-2703.

Orville, R.E., Huffines, G.R., 2001. Cloud-to-ground lightning in the United States: NLDN results in the first decade, 1989-98. Mon. Weather Rev. 129, 1179-1193.

Orville, R.E., Huffines, G.R., Burrows, W.R., Holle, R.L., Cummins, K.L., 2002. The north American lightning detection network (NALDN)—first results: 1998-2000. Mon. Weather Rev. 130, 2098-2109.

Parker, M.D., Rutledge, S.A., Johnson, R.H., 2001. Cloud-to-ground lightning in linear mesoscale systems. Mon. Weather Rev. 129, 1232-1242.

Petersen, W.A., Rutledge, S.A., 1992. Some characteristics of cloud-to-ground lightning in tropical northern Australia. J. Geophys. Res. 97, 11553-11560.

Purdom, J.F.W., 1976. Some uses of high-resolution GOES imagery in the mesoscale forecasting of convection and its behaviour. Mon. Weather Rev. 104, 1474-1483.

Purdom, J.F.W., 1993. Satellite observations of tornadic thunderstorms. Geophys. Monogr. 79, 265-274.

Rakov, V.A., 2000. Positive and bipolar lightning discharges: a review. Proc. 25th Int. Conf. on Lightning Protection, 18-22 September, Rhodes, pp. 103-108.

Rakov, V.A., Huffines, G.R., 2003. Return-stroke multiplicity of negative cloud-to-ground lightning flashes. J. Appl. Meteorol. 42, 1455-1462. 
Rakov, V.A., Uman, M.A., 2003. Lightning_Physics and Effects. Univ. Press, Cambridge. 687 pp.

Rasmussen, E.N., Richardson, S., Straka, J.M., Markowski, P.M., Blanchard, D.O., 2000. The association of significant tornadoes with a baroclinic boundary on 2 June 1995. Mon. Weather Rev. 128, 174-191.

Reap, R.M., MacGorman, D.R., 1989. Cloud-to-ground lightning: climatological characteristics and relationships to model fields, radar observations, and severe local storms. Mon. Weather Rev. 117, 518-535.

Reynolds, D.W., 1980. Observations of damaging hailstorms from geosynchronous satellite digital data. Mon. Weather Rev. 108, 337-348.

Rison, W., Thomas, R.J., Krehbiel, P.R., Hamlin, T., Harlin, J., 1999. A GPS-based three-dimensional lightning mapping system: initial observations in central New Mexico. Geophys. Res. Lett. 26, 3573-3576.

Rison, W., Krehbiel, P.R., Thomas, R.J., Hamlin, T., Harlin, J., 2001. Three-dimensional lightning observations using a time-of-arrival lightning mapping system. Int. Conf. on Lightning and Static Elec. Society of Automotive Engineers, Seattle.

Rutledge, S.A., MacGorman, D.R., 1988. Cloud-to-ground lightning activity in the 10-11 June 1985 mesoscale convective system observed during the Oklahoma-Kansas PRE-STORM project. Mon. Weather Rev. 116, $1393-1408$.

Rutledge, S.A., Petersen, W.A., 1994. Vertical radar reflectivity structure and cloud-to-ground lightning in the stratiform region of MCSs: further evidence for in situ charging in the stratiform region. Mon. Weather Rev. $122,1760-1776$.

Rutledge, S.A., Lu, C., MacGorman, D.R., 1990. Positive cloud-to-ground lightning in mesoscale convective systems. J. Atmos. Sci. 47, 2085-2100.

Saunders, C.P.R., 1993. A review of thunderstorm electrification processes. J. Appl. Meteorol. 32, $642-655$.

Saunders, C.P.R., Keith, W.D., Mitzeva, R.P., 1991. The effect of liquid water on thunderstorm charging. J. Geophys. Res. 96D, 11007-11017.

Schmetz, J., Tjemkes, S.A., Gube, M., van de Berg, L., 1997. Monitoring deep convection and convective overshooting with METEOSAT. Adv. Space Res. 19, 433-441.

Seimon, A., 1993. Anomalous cloud-to-ground lightning in an F5-tornado-producing supercell thunderstorm on 28 August 1990. Bull. Am. Meteorol. Soc. 74, 189-203.

Seity, Y., Soula, S., Tabary, P., Scialom, G., 2003. The convective storm system during IOP 2a of MAP: cloud-toground lightning flash production in relation to dynamics and microphysics. Q. J. Royal Meteorol. Soc. 129, $523-542$.

Shepherd, T.R., Rust, W.D., Marshall, T.C., 1996. Electric fields and charges near $0{ }^{\circ} \mathrm{C}$ in stratiform clouds. Mon. Weather Rev. 124, 919-938.

Stolzenburg, M., 1994. Observations of high ground flash densities of positive lightning in summertime thunderstorms. Mon. Weather Rev. 122, 1740-1750.

Stolzenburg, M., Marshall, T.C., Rust, W.D., Smull, B.F., 1994. Horizontal distribution of electrical and meteorological conditions across the stratiform region of a mesoscale convective system. Mon. Weather Rev. $122,1777-1797$.

Thomas, R.J., Krehbiel, P.R., Rison, W., Hamlin, T., Harlin, J., Shown, D., 2001. Observations of VHF source powers radiated by lightning. Geophys. Res. Lett. 28, 143-146.

Turman, B.N., Tettelbach, R.J., 1980. Synoptic-scale satellite lightning observations in conjunction with tornadoes. Mon. Weather Rev. 108, 1878-1882.

Uman, M.A., 2001. The Lightning Discharge. Dover Publ., Mineola. 377 pp.

Williams, E.R., 1989. The tripole structure of thunderstorms. J. Geophys. Res. 94D, 13151-13167.

Williams, E.R., 2001. The electrification of severe storms. Meteor. Monogr. 28 (50), 527-561.

Williams, E.R., Boldi, B., Matlin, A., Weber, M., Hodanish, S., Sharp, D., Goodman, S., Raghavan, R., Buechler, D., 1999. The behavior of total lightning activity in severe Florida thunderstorms. Atmos. Res. 51, $245-265$.

Zajac, B.A., Rutledge, S.A., 2001. Cloud-to-ground lightning activity in the contiguous United States from 1995 to 1999 . Mon. Weather Rev. 129, 999-1019.

Zipser, E.J., Lutz, K., 1994. The vertical profile of radar reflectivity of convective cells: a strong indicator of storm intensity and lightning probability? Mon. Weather Rev. 122, 1751-1759. 